
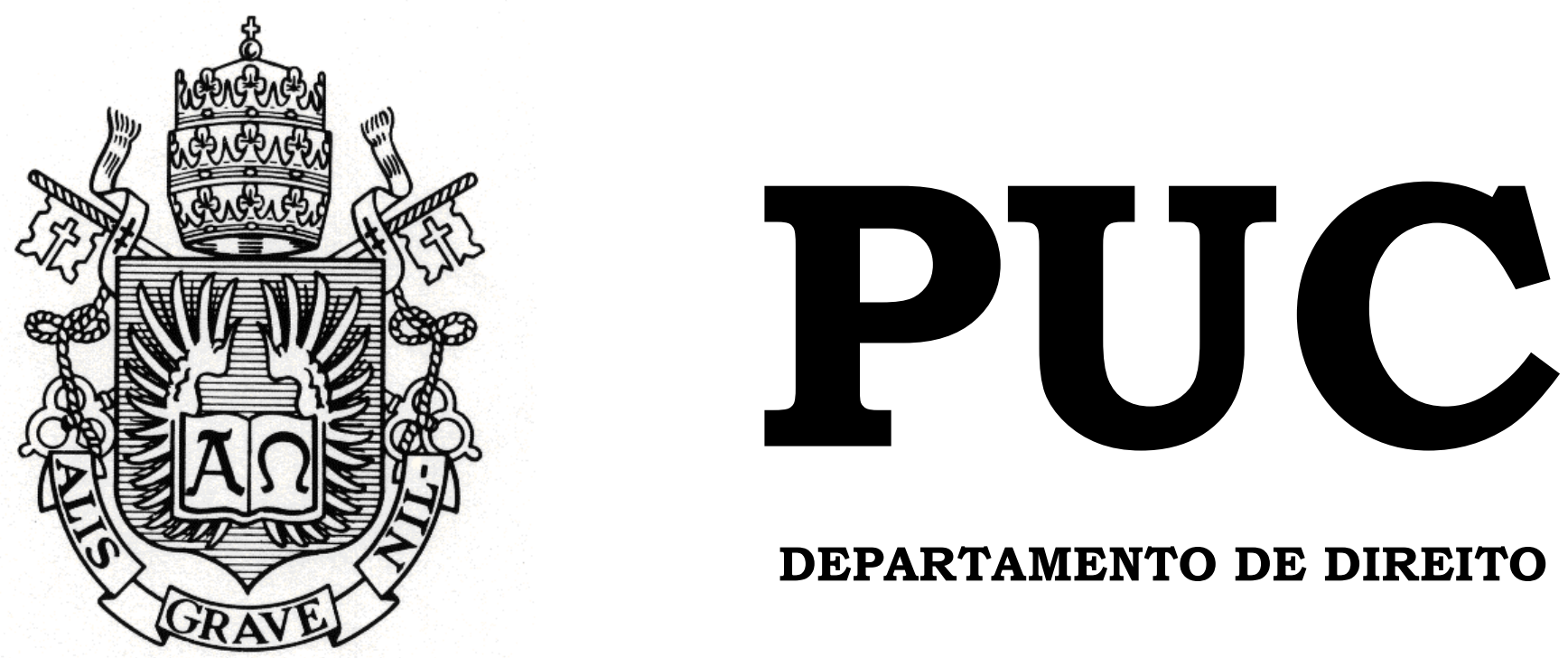

DEPARTAMENTO DE DIREITO

\title{
O DIREITO À MORTE ASSISTIDA À LUZ DO ORDENAMENTO JURÍDICO BRASILEIRO
}

por

ALICE MAC DOWELL VERAS

ORIENTADOR(A): ANDRÉ PERECMANIS

2018.2

PONTIFÍCIA UNIVERSIDADE CATÓLICA DO RIO DE JANEIRO

RUA MARQUÊS DE SÃO VICENTE, 225 - CEP 22453-900

RIO DE JANEIRO - BRASIL 


\title{
O DIREITO À MORTE DIGNA À LUZ DO ORDENAMENTO JURÍDICO BRASILEIRO
}

\author{
por

\section{ALICE MAC DOWELL VERAS}

\section{Monografia}

apresentada

ao

Departamento de Direito da Pontificia

Universidade Católica do Rio de Janeiro (PUC-Rio) para a obtenção do Título de Bacharel em Direito.

Orientador(a): ANDRÉ PERECMANIS 


\section{RESUMO}

Os constantes avanços tecnológicos que permeiam o cenário contemporâneo, ao passo que possibilitam a salvação de diversas vidas outrora perdidas, podem ser igualmente responsáveis por causar dor e sofrimento a pacientes terminais em razão de uma tentativa vã de se alongar suas vidas biológicas. Outrossim, ainda que não portadoras de doenças que se encontram em estágio terminal, milhões de pessoas são acometidas por enfermidades psiquiátricas consideradas irremediáveis, que causam intensos sofrimentos psíquicos e fazem com que o desejo de estar vivo não mais exista. Seja qual for o contexto, a questão que fica é a se essas pessoas possuem o direito à morte digna, auxiliada ou executada, ainda que na forma omissiva, por um terceiro. A presente monografia tem como objetivo analisar as modalidades de morte com intervenção sob a ótica do ordenamento jurídico pátrio, especificamente do princípio da dignidade da pessoa humana e autonomia existencial, bem como a possibilidade de regulamentação, tendo como base parâmetros estabelecidos por legislações alienígenas.

\section{PALAVRAS-CHAVE}

Morte Digna; Suicídio Assistido; Eutanásia; Ortotanásia; Distanásia; Dignidade da Pessoa Humana; Autonomia; Direito à Vida 


\section{SUMÁRIO}

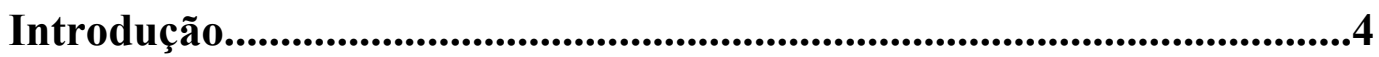

Capítulo 1 - Morte com intervenção e suas modalidades à luz da legislação penal brasileira....................................................................................7

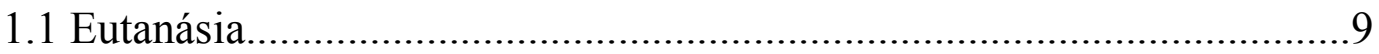

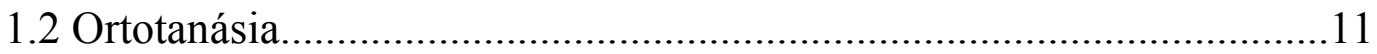

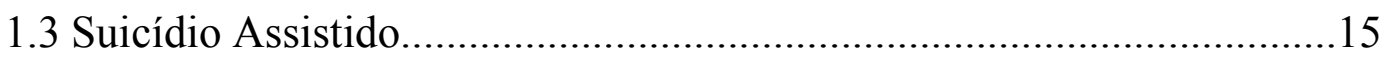

Capítulo 2 - Autonomia para morrer no direito comparado.................21

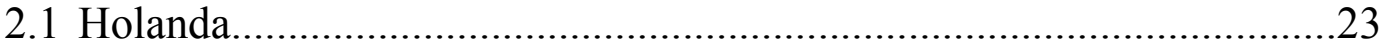

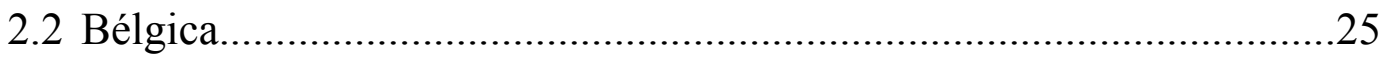

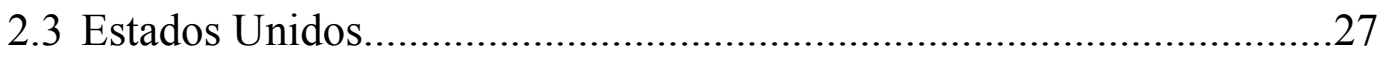

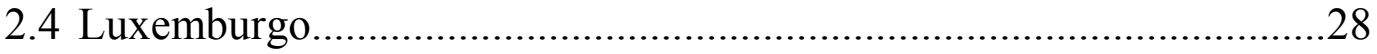

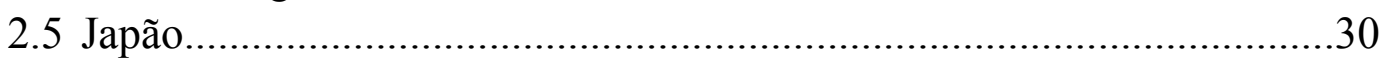

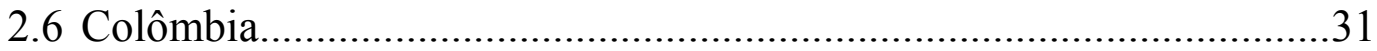

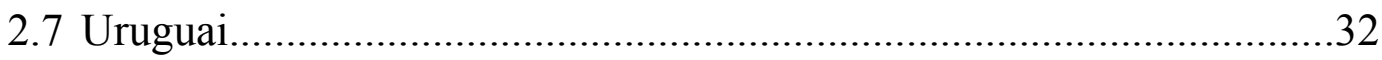

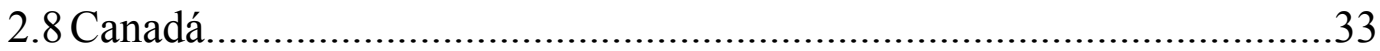

Capítulo 03 - A dignidade da pessoa humana e a morte assistida.............34

3.1 O princípio da dignidade da pessoa humana: contornos e alcance..........35

3.1.1 Dignidade da pessoa humana como autonomia.....................................39

3.1.2 Dignidade da pessoa humana como heteronomia.................................41

3.2 Morte assistida na Constituição Federal de 1988 - dignidade da pessoa

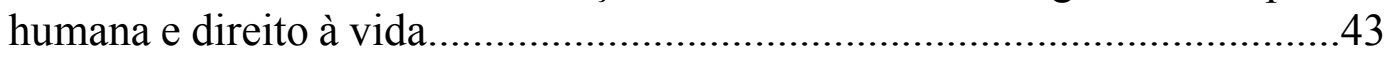

3.3 Proposta de regulamentação à morte com intervenção.............................48

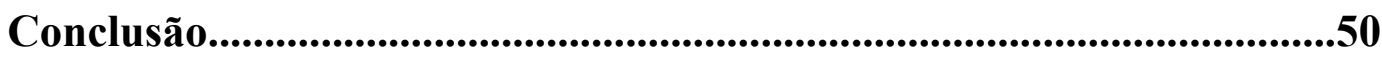




\section{INTRODUÇÃO}

A passagem do século XIII para o século XIX é marcada pela transformação acerca do conceito de autonomia do indivíduo. Se antes, no Estado Liberal Burguês, o sujeito era visto única e exclusivamente como um negociador, agora ele passa a ser visto como sujeito de direitos.

É nesse contexto que a autonomia, no passado vista como autonomia da vontade, conferida ao indivíduo para que negociasse livremente e estando circunscrita na esfera contratual, vai assumindo contornos diferentes, e é deslocada para a esfera de direitos pessoais do próprio indivíduo e o desenvolvimento de sua pessoalidade enquanto pessoa humana.

Aliado a isto, marcos históricos como a Segunda Guerra Mundial fizeram com que a esmagadora maioria dos países adotasse o compromisso com a dignidade da pessoa humana, seja por meio de tratados e documentos internacionais, seja por meio de suas legislações internas. Muito embora a dignidade ocupe posição central em diversos ordenamentos jurídicos, sendo considerada, inclusive, como marco civilizatório por muitos juristas, não tem sido tarefa fácil definir seu conceito e alcance.

O fato de possuir contornos porosos, bem como de ocupar posição privilegiada, isto é, de verdadeiro vetor axiológico, em relação a todo o ordenamento jurídico, faz com que lados rivais de discussões emblemáticas envolvendo o ser humano invoquem o princípio da dignidade da pessoa humana como fundamento para a sua argumentação. O debate em torno da morte assistida não poderia ser diferente.

A certeza quanto à finitude da vida não exclui a possibilidade de alguém pretender antecipar sua morte. Seja porque está acometido por doença que cause grande sofrimento - físico ou mental -, seja porque

simplesmente não possui mais vontade de estar vivo, teria o indivíduo o direito de ser auxiliado por terceiro com o fim de obter uma morte digna?

Aqueles que se posicionam contrariamente à regulamentação da morte assistida, afirmam, em síntese, que a decisão quanto ao momento do fim não 
caberia ao ser humano, de modo que delegar essa escolha a alguém representaria violação ao direito à vida e, por conseguinte, à dignidade da pessoa humana. Esse freio à autonomia individual pode ser ainda justificado pela tentativa de coibir práticas abusivas que poderiam surgir a partir da regulamentação, entendendo a vida como um bem em si.

Por outro lado, quem se mostra favorável à medida, aduz, em resumo, que a dignidade da pessoa humana é verificada na autonomia individual, de modo que retirar do indivíduo seu poder de autodeterminação é violar a sua dignidade enquanto pessoa humana. Além disso, a vida, assegurada constitucionalmente, não é compreendida única e exclusivamente pelo seu caráter biológico, como também por diversos outros fatores. A formulação existencial de que o direito à vida requer uma absoluta proibição à morte assistida ou que os indivíduos não podem "renunciar" ao seu direito à vida, acaba por criar um verdadeiro "dever de viver" ao invés de um "direito à vida".

A relevância da discussão se deve não somente aos aspectos jurídicos que rondam o tema, como também à realidade fática. A ausência de regulamentação acerca da morte assistida acaba por levar pessoas que ainda poderiam viver por mais tempo em boas condições a se suicidarem, vez que preferem colocar fim à sua vida quando ainda podem fazer isso por si próprias. São acometidas pelo medo de que a progressão da doença as faça perder o controle e, assim, ficarem presas sem escapatória possível em um corpo destinado a fazê-las sofrer. Por outro lado, muitas pessoas gravemente doentes ou incapacitadas, apesar de plenamente conscientes, são incapazes de suicidar-se sem ajuda.

Sendo assim, o escopo do presente trabalho é analisar a possibilidade de regulamentação quanto à assistência no momento da morte, analisando o princípio da dignidade da pessoa humana como autonomia e construção da pessoalidade do sujeito.

A morte assistida, compreendida pela intervenção de um terceiro no momento do óbito do indivíduo, - seja auxiliando, seja executando ou, inclusive, se omitindo -, sofreu mudanças ao longo dos últimos anos. O que antes era englobado por um único conceito, atualmente é compreendido através de 
categorias específicas. Se a temática já é um debate em si complexo, esbarrando em entraves morais, religiosos e éticos, a incerteza da linguagem dificultava ainda mais sua compreensão.

Ressalte-se, contudo, que o debate promovido pela bioética considera a possibilidade de assistência à morte apenas para pessoas doentes, e, em particular, àquelas em estágio terminal, acometidas por intenso sofrimento físico e para quem a medicina oferece restritas possibilidades de mudança do quadro clínico. ${ }^{1}$ No entanto, como será abordado principalmente quando da morte assistida na legislação comparada, o direito de morrer dignamente pode ser pensado também aos pacientes doentes mentais, ainda que não estejam acometidos por sofrimentos físicos.

A partir desse quadro, no capítulo 01 (um), serão apresentados os conceitos básicos que hoje são utilizados no debate, quais sejam, suicídio assistido, eutanásia e ortotanásia. Além da diferenciação conceitual, se buscou fazer uma breve análise de como a legislação brasileira lida com o advento de cada um deles.

Em seguida, no capítulo 02 (dois), objetivando traçar possíveis formas de regulamentação compatíveis com o ordenamento jurídico brasileiro, é feita uma análise das legislações alienígenas que autorizam a prática, de forma a se compreender as diferenças entre elas, bem como requisitos e regras proced: tais a serem observadas para a prática da morte assistida.

Por fim, no último capítulo, é feita uma análise quanto à trajetória, contornos e alcance do princípio da dignidade da pessoa humana. Nesse sentido, entendendo seu surgimento e posição eminente no ordenamento jurídico, se passa ao exame acerca da sua conceituação. Se de um lado a corrente majoritária compreende a dignidade da pessoa humana como autonomia, há, do outro, aqueles que o enxergam como heteronomia, ou seja, o freio a autonomia a fim de se resguardar o bem-estar da sociedade e, porque não, do próprio indivíduo. Mais adiante, compreendendo os diferentes conceitos acerca da dignidade humana,

\footnotetext{
${ }^{1}$ Pessini, Leocir: Eutanásia: por que abreviar a vida?, São Paulo: Ed. Loyola, 2004. p 74
} 
procurou-se trabalhar a sua expressão na Constituição da República de 1988, e qual seria a posição adotada pelo poder constituinte quando da sua promulgação.

Ao final do capítulo 03 (dois), se avalia de que forma a morte assistida poderia ser enxergada à luz da dignidade da pessoa humana como compreendida na Constituição Federal de 1988. Neste contexto, são apresentados determinados consensos, buscando adequá-los a possíveis soluções regulamentadoras.

\section{Capítulo 01 - MORTE COM INTERVENÇÃO E SUAS MODALIDADES À LUZ DA LEGISLAÇÃO PENAL BRASILEIRA}

O crescente envelhecimento populacional associado ao rápido avanço das tecnologias favorece a ampliação do horizonte de debates sobre o direito de morrer. A preocupação em defender a dignidade da vida humana em sua fase terminal é ponto em comum entre aqueles que defendem a prática da intervenção na morte, discordando, em alguns momentos, apenas quanto aos meios utilizados para que este fim seja alcançado.

A evolução tecnológica no âmbito medicinal reformulou drasticamente as concepções até então postas na sociedade. Atualmente, tanto o início quanto o fim da vida não escapam mais do controle humano como costumavam escapar. No entanto, as conquistas realizadas, ao mesmo tempo que possibilitam a salvação de vidas que antes podiam ser consideradas como perdidas, fazem com que se prolongue um penoso processo de manutenção da agonia e retardamento da morte. ${ }^{2}$ Esta intervenção médica exacerbada e inútil recebeu o nome, pela Bioética, de Distanásia.

A Distanásia é a obstinação terapêutica em que a tecnologia médica é utilizada para prolongar penosa e inutilmente o processo de agonizar e morrer. Trata-se da atitude médica que, visando salvar a vida do paciente terminal,

\footnotetext{
${ }^{2}$ Pessini, Leocir: Eutanásia: por que abreviar a vida?, São Paulo: Ed. Loyola, 2004. p. 85
} 
submete-o a grande sofrimento. Nesta conduta não se prolonga a vida propriamente dita, mas o processo de morrer.

Conforme aduzido por Leocir (2004, p. 96), existe um determinado consenso em se rejeitar a distanásia por parte de autoridades éticas e, inclusive, representantes de diversas religiões. Já em 1957, o papa Pio XII reconhecia que a obrigação de tratar não implicaria em recorrer a medidas terapêuticas inúteis e desproporcionais.

Muito embora exista certa concordância quanto a sua rejeição, o questionamento acerca de até que ponto deve-se prolongar o processo de morrer quando não se tem mais esperança de reverter o quadro do paciente permanece inquietando os estudiosos.

O que tem se verificado é a preocupação exacerbada com a quantidade de vida biológica do paciente, desviando-se o olhar para a qualidade desta vida prolongada. É neste contexto que surgem as espécies de morte com intervenção, ainda que por intervenção se entenda práticas omissivas, como será analisado a seguir.

Em síntese, entende-se por morte assistida a intervenção de um terceiro com vistas a auxiliar - executando, fornecendo meios ou, inclusive, se omitindo determinado indivíduo a morrer de forma digna. Assim, antes de adentrarmos na discussão acerca do cabimento ou não da autorização concedida pelo estado ao terceiro que assiste o indivíduo a morrer com dignidade, relevante analisar determinados conceitos essenciais, bem como cada um deles repercute na legislação brasileira.

De início, ressalte-se que tanto a eutanásia quanto a ortotanásia são conceitos ligados à medicina, utilizados para designar modalidades de morte com intervenção em doentes terminais, acometidas por sofrimento físico ou mental. Por outro lado, o chamado suicídio assistido, conforme se verá a seguir, recebe tipo penal específico, não possuindo, em um primeiro momento, sujeito passivo determinado. Qualquer um pode ser considerado vítima do crime previsto pelo artigo 122 do Código Penal, que existe nas modalidades de instigação, induzimento e auxílio. Ao debate acerca da morte assistida interessa a intervenção 
na forma de auxílio, quando há, por exemplo, prescrição de medicamentos mortais a doentes em sofrimento.

\section{1 - EUTANÁSIA}

Entende-se por eutanásia o atuar médico que, ao tratar de paciente que possua doença incurável e de caráter irreversível, responsável por causar-lhe insuportáveis sofrimentos físicos ou mentais, apresse, de forma intencional, a sua morte. É necessário, contudo, que a atuação médica se dê por motivos de benevolência. Para que se classifique enquanto eutanásia, é preciso que o comportamento tenha se dado com a intenção de beneficiar o doente. Apressar o óbito do paciente por qualquer outra motivação que não a compaixão, é conduta tida como homicídio. ${ }^{3}$

A eutanásia pode ser ativa, quando se induz a morte pela administração de medicamentos, por exemplo, ou passiva, quando se retiram mecanismos de sustentação artificial da vida ou se retiram medicamentos.

Pode ainda ser classificada como voluntária ou involuntária. A eutanásia será voluntária quando oriunda de deliberação individual, informada e esclarecida por parte do paciente, e involuntária quando o doente não se pronunciou e não há como conhecer sua opinião, ou até mesmo quando não desejava a prática da eutanásia. ${ }^{4}$

Ressalte-se, nesse sentido, que o termo eutanásia era utilizado de forma abrangente, caracterizando tanto a conduta comissiva quanto à conduta omissiva do médico. Atualmente, seu emprego se dá única e exclusivamente em casos comissivos, ou seja, quando o médico assume uma postura ativa, seja ela a de administrar medicamentos, ou desligar aparelhos.

\footnotetext{
${ }^{3}$ Pessini, Leocir. Op. Cit. p.259

4 SARMENTO, Daniel. Dignidade da Pessoa Humana: conteúdo, trajetórias e metodologia. Belo Horizonte: Fórum, 2016. p. 299
} 
Ao contrário do que ocorre em ordenamentos jurídicos de diversos países, não há na legislação brasileira previsão específica quanto à figura da eutanásia.

A prática da eutanásia é punida no Brasil por via do artigo 121 do Código Penal, vez que, ainda que se tenha o consentimento do paciente, o médico que a realiza entra na esfera de atos executórios que ocasionarão a sua morte.

Assim, elemento diferenciador entre o crime do artigo 122, na forma do auxílio, e o crime em comento, é, justamente, a prática de qualquer ato executório. Ou seja, a partir do momento que o agente entra na esfera de atos executórios, o crime praticado passa a ser o de homicídio.

Ao contrário do que ocorre no auxílio ao suicídio, entende-se que no crime em tela poderá haver atenuação da pena quando for praticado por razões altruístas. Conforme se verifica do $\S 1^{\circ}$ do artigo 121 do Código Penal, tendo sido o agente "impelido por motivo de relevante valor social ou moral, ou sob o domínio de violenta emoção, logo em seguida a injusta provocação da vítima, o juiz pode reduzir a pena de um sexto a um terço".

Pergunta-se, portanto: estando o agente incurso nas penas do artigo 121 do Código Penal em razão de ter praticado ato executório que vise a morte da vítima, acometida por doença incurável que lhe cause intenso sofrimento, a seu pedido ou não, teria a sua pena diminuída caso tenha agido impelido por relevante valor social ou moral?

Há convergência doutrinária no sentido de se considerar o homicídio como privilegiado, já que o médico agiria com o fim de acabar com o penar de outrem.

A prática da eutanásia no Brasil é recriminada não só sob a ótica do direito penal, como também da ética que rege a prática da medicina.

De acordo com o artigo 41 do Código de Ética Médica ${ }^{5}$, é vedado ao médico abreviar a vida do paciente, ainda que a pedido deste ou de seu representante legal.

\footnotetext{
${ }^{5}$ Código de Ética Médica.

Art. 41. Abreviar a vida do paciente, ainda que a pedido deste ou de seu representante legal.

Parágrafo único. Nos casos de doença incurável e terminal, deve o médico oferecer todos os cuidados paliativos disponíveis sem empreender ações diagnósticas ou terapêuticas inúteis ou obstinadas, levando
} 
Também é previsto que, em casos de doença incurável e terminal, é dever do médico oferecer todos os cuidados paliativos disponíveis sem empreender ações diagnósticas ou terapêuticas inúteis ou obstinadas.

\section{2 - ORTOTANÁSIA}

A ortotanásia é "a morte em seu tempo adequado, não combatida com os métodos extraordinários e desproporcionais como na distanásia, nem apressada por ação intencional externa, como na eutanásia." (MARTEL e BARROSO, 2010, p.179).

Nessa perspectiva, a ortotanásia significa o respeito por parte do médico, concluindo pela instalação de quadro irreversível e letal, ao curso natural da morte do paciente, sem intervenções que objetivem alongar a sua vida biológica de forma artificial e despropositada.

Do ponto de vista constitucional, conforme será analisado mais detidamente a seguir, a ortotanásia poderia ser considerada prática lícita, vez que, de acordo com o inciso III do artigo $5^{\circ}$ "ninguém será submetido a tortura nem a tratamento desumano ou degradante".

A bem da verdade, submeter alguém a tratamento indesejado, por tempo indeterminado, gerador de agonia e sofrimento, priorizando a manutenção da vida biológica a qualquer custo e sob quaisquer condições, é conduta facilmente identificada àquela que a Constituição Federal buscou reprimir.

No entanto, sob a ótica do Direito Penal, a ortotanásia continua sendo identificada como crime de homicídio. Todavia, ao invés de ser classificada como conduta comissiva, como é o caso da eutanásia, é constituída na modalidade omissiva, vez que a conduta médica se resume a deixar de administrar medicamentos ou promover tratamentos. Veja-se, portanto, a diferença entre a 
ortotanásia e a eutanásia passiva. Enquanto esta é compreendida por uma atitude, ainda que a de desligar aparelhos, aquela é tida como a ausência de intervenção.

Em 2006, o Conselho Federal de Medicina se posicionou sobre o tema, editando a Resolução 1.805/2006, que conferia ao médico a possibilidade de "liminar ou suspender procedimentos e tratamentos que prolonguem a vida do doente em fase terminal, de enfermidade grave e incurável, respeitada a vontade da pessoa ou de seu representante legal." 6

Com efeito, determinados requisitos deveriam ser respeitados, tais como o esclarecimento ao paciente ou ao seu representante legal quanto às formas de tratamento para cada situação, a fundamentação e registro em prontuário da decisão médica pela ortotanásia, e a informação ao paciente quanto ao seu direito de consultar a opinião de outro profissional. ${ }^{7}$

A norma garantia ainda que o doente continuasse a receber todos os cuidados necessários para alívio do sofrimento, assegurando-lhe conforto, assistência integral e direito de alta hospitalar.

O Ministério Público Federal, então, considerando que a ortotanásia configuraria prática homicida, bem como que representaria "mero desejo de dar ao homem, pelo próprio homem, a possibilidade de uma decisão que nunca lhe pertenceu", interpôs ação civil pública requerendo, liminarmente, a suspensão da Resolução editada pelo Conselho Federal de Medicina ${ }^{8}$. O procurador subscritor afirmou, ainda, que a pressão exercida pelos planos de saúde ou a falta de infraestrutura hospitalar comum ao Brasil poderia interferir na decisão.

O juiz de primeiro grau, na decisão que concedeu o requerimento liminar do Ministério Público Federal, suspendeu a eficácia da Resolução, aduzindo para

\footnotetext{
${ }^{6}$ Artigo $01^{\circ}$ da Resolução 1.805/2006 do Conselho Federal de Medicina

${ }^{7}$ Artigo $01^{\circ}, \S \S 1^{\circ}, 2^{\circ}$ e $3^{\circ}$ da Resolução $1.805 / 2006$ do Conselho Federal de Medicina

${ }^{8}$ Ministério Público Federal. Procuradoria da República no Distrito Federal. Procuradoria Regional dos Direitos de Cidadão. Ação Civil Pública número 2007.34.00.014809-3, da 14a Vara Federal. Disponível em: http://www.mpf.mp.br/pgr/copy_of_pdfs/ACP\%20Ortotanasia.pdf/view. Acessado em 2018 (20 nov.).
} 
tanto que, à primeira vista, o conteúdo da referida norma conflitava com o Código Penal brasileiro.

No entanto, em 01 de dezembro de 2010, foi proferida sentença julgando improcedente o requerimento ministerial, aduzindo para tanto que a Resolução não ofenderia o ordenamento jurídico posto, vez que a ortotanásia significaria apenas deixar que o processo mortal do paciente siga seu curso natural, não havendo interferências artificiais ao longo do caminho. Outrossim, afirmou que a Constituição da República reconheceria o princípio da dignidade da pessoa humana como fundamento do Estado Democrático de Direito e, como desdobramento deste, assegura, expressamente, que ninguém será submetido à tortura nem a tratamento desumano ou degradante. ${ }^{9}$

Em 2012 o Conselho Federal de Medicina editou nova Resolução (1.995/2012) visando regulamentar a prática da ortotanásia, atendendo para a necessidade do paciente que, em determinado estágio, fica impossibilitado de expressar a sua vontade, valorizando o princípio da autonomia do paciente e dispondo acerca das diretivas antecipadas de sua vontade.

Conforme se depreende da norma, ao paciente está autorizado que defina suas diretivas - conjunto de desejos -, de forma prévia e antecipada, quanto aos tratamentos que deseja ou não receber quando do avanço do seu quadro terminal, devendo estas serem respeitadas pelo médico. Ressalte-se, inclusive, que as diretivas antecipadas do paciente prevalecerão sobre qualquer outro parecer não médico, inclusive o desejo dos familiares.

Em face desta nova Resolução, o Ministério Público Federal interpôs nova Ação Civil Pública, requerendo fosse declarado inconstitucional o ato administrativo, pois, além de o Conselho Federal de Medicina supostamente não possuir competência para regulamentar a material, a medida representaria riscos à segurança jurídica, retirando da família do paciente decisões que lhe seriam de

\footnotetext{
${ }^{9}$ Sentença proferida em 01 de dezembro de 2010 nos autos do Processo no 0014718-75.2007.4.01.3400 em trâmite junto à da $14^{\mathrm{a}}$ Vara Federal Distrito Federal. Disponível em https://www.conjur.com.br/dl/sentencaresolucao-cfm-180596.pdf . Acessado em 2018 (20 nov.).
} 
direito, bem com investindo o médico da condição de "senhor absoluto" do cumprimento das diretivas com base em instrumento inidôneo. Outro vício constante da Resolução segundo o órgão ministerial seria o fato de não exigir capacidade civil por parte do paciente para que manifeste sua vontade, deixando a decisão a cargo do médico, que não possuiria conhecimentos técnico-jurídicos para arbitrar acerca da decisão.

Em face da Ação Civil Pública interposta, foi proferida, em 2014, sentença declarando improcedente o requerimento ministerial, tendo em vista que a União outorgara ao Conselho Federal de Medicina a competência para legislar quanto à ética e exercício da Medicina, bem como que a Resolução impugnada não teria o condão de criar direitos ou obrigações nas esferas cível e penal, tão somente assegurar ao médico que, ao atender aos requisitos do ato administrativo, não sofreria sanções ético-disciplinares que pudessem ser impostas pelo órgão. No que tange à decisão familiar, o magistrado atentou para o fato de que, caso discordem ou verifiquem qualquer ilícito por parte do médico, estariam aptos a buscar, no caso concreto, tutela judicial com o fim de invalidar o documento assinado pelo doente. Por fim, afirmou que a Resolução seria compatível com o princípio da dignidade da pessoa humana, que, além de assegurar a autonomia individual, garante que ninguém será submetido à tortura ou tratamento desumano e degradante (artigo $1^{\circ}$, inciso III, e artigo $5^{\circ}$, inciso III, da Constituição Federal). ${ }^{10}$

Tendo sido interposta apelação pelo Ministério Público Federal, os autos foram remetidos ao Tribunal Regional Federal da $1^{a}$ Região, sendo certo que até $o$ momento não foi proferida decisão. ${ }^{11}$

Atendendo pela necessidade de legislação específica acerca do tema, o exSenador Gerson Camata, do antigo PMDB, propôs Projeto de Lei que altera o Código Penal para acrescer artigo 136-A, que exclui a ilicitude do crime de maus

\footnotetext{
10 Sentença proferida nos autos do processo $\mathrm{n}^{\mathrm{o}}$ 1039-86.2013.4.01.3500 em 21 de fevereiro de 2014 Disponível em https://testamentovital.com.br/wp-content/uploads/2018/05/senten\%C3\%A7a-ACPtestamento-vital.pdf

${ }^{11}$ Tramitação processual disponível em https://processual.trf1.jus.br/consulta Processual/processo .hp?proc $=00010398620134013500 \&$ secao=TRF1\&pg=1\&enviar=Pesquisar
} 
tratos quando o médico, no âmbito dos cuidados paliativos aplicados a paciente terminal, não fizer uso de meios desproporcionais e extraordinários, quando a morte for iminente e inevitável, desde que o paciente tenha consentido, ou, na sua impossibilidade, o cônjuge, companheiro, ascendente, descendente ou irmão. ${ }^{12}$

O Projeto de Lei prevê, ainda, que a morte do paciente deve ter uma previsibilidade de no máximo 02 (dois) anos, bem como que a ilicitude não será excluída em casos em que deixam de ser administrados meios terapêuticos ordinários e proporcionais devidos a paciente terminal.

Após a aprovação pelo Senado Federal, o Projeto de Lei foi remetido à Câmara dos Deputados, estando sob a análise da Comissão de Constituição e Justiça e de Cidadania desde junho do corrente ano, tendo sido designado como relator o deputado Marco Feliciano (PODE-SP). ${ }^{13}$

Diante da ausência de legislação específica acera da prática ortotanásia, reputa-se como válida, em atenção às Resoluções editadas pelo Conselho Federal de Medicina, a conduta médica que não interfere, mediante a utilização de tratamentos desnecessários, no processo letal natural do paciente terminal.

\section{3 - SUICÍDIO ASSISTIDO}

Ao contrário das demais espécies de morte com intervenção, o chamado suicídio assistido recebe tratamento especial por parte da legislação penal brasileira, encontrando-se tipificado pelo artigo 122 do Código Penal, considera conduta típica, antijurídica e culpável "Induzir ou instigar alguém a suicidar-se ou prestar-lhe auxílio para que o faça".

Destarte,

“diversamente do que ocorre no homicídio, no delito em tela o agente não suprime a vida de outrem, mas promove - através da indução, da instigação ou do auxílio - sua destruição

\footnotetext{
${ }^{12}$ Projeto de Lei do Senado $n^{\circ} 116$, de 2000, de autoria do Senador Gerson Camata.

13 Tramitação processual disponível em < http://www.camara.gov.br/proposicoesWeb/fichadetramitacao?idProposicao $=465323>$
} 
pelo próprio titular da mesma. Insta destacar, todavia, que não é o sujeito ativo partícipe do suicídio alheio - visto que tal ato é impunível -, mas autor de delito autônomo, perfeitamente configurado com a prática de qualquer uma das condutas descritas no tipo penal.". ${ }^{14}$

Muito embora sejam consideradas elementares do tipo a prática de 03 (três) condutas - induzir, instigar e auxiliar - o agente, ainda que leve a cabo mais de um dos comportamentos descritos, responderá por uma única infração penal.

Entende-se por induzimento fazer nascer no sujeito passivo a ideia suicida, enquanto por instigação estimular uma ideia preexistente, sendo certo que ambas as condutas indicam uma participação de ordem moral.

É necessário, contudo, que o induzimento ou a instigação tenham contribuído de forma efetiva para que a vítima decidisse por fim à própria vida, ou levasse adiante a ideia já em formação de se matar.

Em relação ao auxílio, a participação do agente passa a ser de ordem material, de modo que o sujeito ativo concorre materialmente para o resultado morte, seja fornecendo instrumentos que possam levar a vítima a ceifar a própria vida - como a prescrição de medicamentos, por exemplo -, seja fornecendo informações ou orientações no mesmo sentido.

Caso, entretanto, a vítima utilize outro método ou instrumento não fornecido pelo agente, é possível que o auxílio prestado, ainda que não explorado, passe a ser caracterizado como instigação, já que se contribuiu de alguma forma para que fosse solidificada no sujeito passivo a ideia suicida.

Com efeito, é necessário que as três condutas - instigar, induzir ou auxiliar - guardem com a ação da vítima eficiência causal. Ou seja, é preciso que o agente tenha de fato contribuído, por meio de um, ou mais, dos comportamentos descritos na norma, ao evento morte intentado pelo suicida.

No que tange ao auxílio material, importante assinalar que este deve estar circunscrito entre os atos preparatórios do suicídio, vez que, a partir do momento

\footnotetext{
${ }^{14}$ REGIS PRADO, Luiz. Tratado de Direito Penal Brasileiro: Parte Especial Arts. 121 ao 183. p. 109
} 
que o agente ingressa na seara de execução, estará incurso nas penas do artigo 121 do Código Penal.

Ainda que ao sujeito ativo seja solicitado pelo suicida a prática de determinado ato executório - como, por exemplo, o desligamento de aparelhos médicos ou aplicação de injeções letais -, sua conduta, deixando de ser secundária e acessória, será tipificada como crime de homicídio.

No exemplo trazido por Nélson Hungria (1981, p.232), um casal de namorados opta por morrer juntos asfixiados por gás carbônico,

“e, enquanto um abria o bico de gás, o outro calafetava as frinchas do compartimento. Se qualquer deles sobrevive, responderá por homicídio, pois concorreu materialmente no ato executivo da morte do outro. Se ambos sobrevivem, responderão por tentativa de homicídio. No caso em que somente um deles tivesse calafetado as frestas e aberto o bico de gás, responderá este, na hipótese de sobrevivência de ambos, por tentativa de homicídio, enquanto o outro responderá por instigação a suicídio".

Assim, ainda que com o consentimento da vítima, que almeja a própria morte e solicita ao agente que pratique qualquer ato para que este resultado seja alcançado, vindo o terceiro a praticar o aludido ato, estará incurso nas penas do artigo 121 do Código Penal.

Ou seja, para que se perfaça o crime previsto pelo artigo 122 do Código Penal, todos os atos executórios devem ser praticados pela vítima, cabendo a ela o domínio final do fato.

Verifica-se, portanto, que, quando se tem a participação material do agente, conduta descrita pelo tipo penal como auxilio, o bem jurídico vida é destruído pela própria vítima, que pratica todos os atos executórios e possui o domínio final do fato.

Não se trata de crime próprio, de modo que, tanto o sujeito passivo quanto o sujeito ativo podem ser quaisquer pessoas, não havendo restrições nesse sentido.

Ressalte-se, outrossim, que, à consumação do tipo penal, é necessário que a vítima possua capacidade de discernimento e de autodeterminação, pois, caso contrário, a conduta praticada pelo agente passa a ser a de homicídio. 
Impende ressaltar, conduto, que, para que se reste caracterizado o crime de homicídio, é preciso que a incapacidade da vítima possua caráter permanente, de modo que, sendo transitória, o crime praticado será o do artigo 122 do Código Penal, tendo sua pena aumentada em razão do inciso II.

Questão controvertida na doutrina é a que diz respeito à omissão do agente. Poder-se-ia punir aquele que, apesar de ter meios para tanto, não impede o suicídio de se consumar?

Parte da doutrina afirma que, se o sujeito ativo ocupa a função de garantidor e se omite da ação a que estava obrigado apesar de possuir capacidade concreta de agir, sua conduta negativa contribuiria para o advento do suicídio, vez que a omissão guardaria conexão com o resultado alcançado pela vítima. Por outro lado, verifica-se que parte majoritária da doutrina rejeita a hipótese de se condenar aquele que deixa de agir para impedir a prática do suicídio, vez que "não se pode ver assistência material na simples inércia, na conduta puramente negativa, ou de quem nada faz, ainda quando tivesse o dever jurídico de o fazer". ${ }^{15}$

De acordo com Luiz Regis Prado (2017, p.113), a posição de garantidor ocupada pelo agente, como seria o caso do médico, deixa de existir ou desaparece a partir do momento em que há a recusa por parte do suicida da ajuda a ser prestada para impedir que o suicídio se consume.

Entendendo este comportamento como uma tentativa de suicídio, ainda que a vítima seja maior e capaz, o médico, sendo imprescindível essa transfusão, poderá realizá-la ainda que sem o seu consentimento.

O artigo 146, $\S 3^{\circ}$, I do Código Penal, prevê que não se configura constrangimento ilegal a "intervenção médica ou cirúrgica, sem o consentimento do paciente ou de seu representante legal, se justificada por iminente perigo de vida".

É elemento subjetivo do crime em comento o dolo por parte do agente, podendo este ser direto ou eventual. Não há previsão legal do crime em sua

\footnotetext{
${ }^{15}$ SILVEIRA, E.C. da. Direito Penal. Crimes contra a pessoa. p. 76
} 
modalidade culposa, de modo que, para que o agente seja punido, é imprescindível a presença do dolo. Ou seja, é preciso não só que o agente tenha consciência do que está fazendo e da ilicitude da sua conduta, como também deseje o resultado. Outrossim, destaca-se a possibilidade de punir o agente que, não almejando o resultado morte, assume o risco de produzi-lo, restando caracterizado o dolo eventual.

No que diz respeito à natureza jurídica do tipo questão, da sua leitura, em um primeiro momento, poderia se concluir tratar-se de crime formal, vez que, estabelecidas as elementares - induzir, instigar ou auxiliar -, não se vislumbra a necessidade do resultado morte ou lesão corporal.

Até porque, importante ressaltar, o alcance do resultado morte está longe da esfera de controle do agente, de modo que, mais coerente seria se a consumação do crime prescindisse do resultado.

No entanto, o crime previsto pelo artigo 122 do código penal é de natureza material, sendo certo que o agente só será punido caso a vítima logre êxito em tirar a própria vida, ou, de sua tentativa, resulte lesão corporal grave. Assim, para a sua consumação, é necessário o advento de um dos dois resultados.

Veja-se, portanto, que, ainda que o agente pratique qualquer das condutas descritas no tipo penal levando a vítima a praticar determinado ato que vise abreviar a sua própria morte, não sendo atingida a integridade corporal da vítima de forma grave, por circunstancias alheias a quaisquer das vontades - seja do agente, seja da vítima -, a conduta passa a ser atípica, não se podendo falar em punição.

Previsto enquanto crime doloso contra a vida, seu processamento e julgamento será feito perante o tribunal do júri, conforme competência estabelecida constitucionalmente (artigo $5^{\circ}$, xxxvii, d, CF). Por sua vez, ao contrário dos demais crimes submetidos a julgamento popular, o crime previsto pelo artigo 122 do Código Penal prescinde do resultado morte para que seja considerado consumado. 
Isso porque, àquele que pratica uma ou mais das condutas previstas pelo tipo penal e, da conduta levada a cabo pelo suicida, seja verificada lesão corporal grave, foi reservado novo preceito secundário. A quem comete o delito, está prevista a pena de "reclusão, de dois a seis anos, se o suicídio se consuma; ou reclusão, de um a três anos, se da tentativa de suicídio resulta lesão corporal de natureza grave.”.

Vê-se, portanto, que, neste caso, não terá o agente a sua pena diminuída em razão do artigo 14, II, do Código Penal, mas estará submetido a um novo parâmetro de pena.

No caso de o sujeito passivo, tendo sido influenciado ou auxiliado pelo agente a atentar contra a própria vida, e, desta tentativa, se lesionar de maneira leve, a conduta será considerada atípica.

Não há que se falar, portanto, em crime tentado no caso de o agente, apesar de ter praticado quaisquer das condutas descritas pelo tipo - induzir, instigar ou auxiliar-, não lograr êxito em fazer com que a vítima tente se matar. O crime em tela, portanto, não é admitido na sua forma tentada, seja porque não sendo obtido o resultado morte, mas sim lesão corporal grave, o crime é considerado consumado, seja porque se desse fato resultar lesão corporal leve, a conduta é atípica.

Duas são as causas de aumento de pena previstas pelo artigo 122 do Código Penal, quais sejam, se o crime for cometido em razão de motivação egoísta por parte do agente, e se a vítima possuir menos de 18 (dezoito) anos a a capacidade de resistência diminuída por qualquer outro motivo.

No que tange ao inciso I, relacionado ao foro íntimo do agente, observa-se a intenção por parte do legislador em evitar que o crime se dê por motivos econômicos, no caso de, por exemplo, uma filha que, objetivando se beneficiar da herança da mãe, a instigue a se matar.

Por outro lado, no inciso II da referida norma, o legislador repousou seu olhar sobre a vulnerabilidade da suposta vítima, prevendo que, sendo menor ou tendo sua capacidade de resistência diminuída, será duplicada a pena do agente. 
Importante mencionar que, em relação à menoridade, travam-se debates quanto à relatividade da vulnerabilidade. Isso porque, a norma insculpida no inciso II menciona tão somente a palavra "menor", não importando, em um primeiro momento, a idade precisa da vítima. Entende-se, contudo, que, sendo a vítima menor de 14 (quatorze) anos, o crime passa a ser o de homicídio.

Quanto à diminuição da capacidade de resistência como causa de aumento de pena, ressalte-se não se tratar de eliminação desta, mas tão somente sua diminuição. Conforme acima mencionado, em caso de eliminação permanente da capacidade de resistência, a regra segue a tendência da menoridade abaixo de 14 (quatorze) anos, e o agente estará incurso nas penas do artigo 121 do Código Penal.

Assim, restando verificado qualquer coação física ou moral, debilidade mental ou erro provocado por terceiro, o agente será punido como autor mediato do crime de homicídio.

\section{Capítulo 02 - AUTONOMIA PARA MORRER NO DIREITO COMPARADO}

A repressão à morte assistida não é exclusividade brasileira, sendo certo que a maioria dos ordenamentos jurídicos consideram como criminosa a conduta daquele que participa do processo letal alheio, seja praticando algum ato executório, seja auxiliando o indivíduo que irá, por si próprio, atentar contra a própria vida.

No que tange ao artigo 122 do Código Penal brasileiro, o único na legislação pátria a tratar do assunto de forma específica, verifica-se que sua edição, ainda no Código Criminal brasileiro de 1830, sofreu influência do primeiro texto legal que tratou do assunto, o Projeto de Código Penal elaborado por Livingston à Lousiana, em 1822. Posteriormente, os Códigos Penais espanhol (1848) e toscano (1853) também o adotaram à sua maneira.

O Código Criminal brasileiro de 1830, dispunha em seu artigo 196, inserido no capítulo I (Dos crimes contra a segurança da pessoa e vida), Titulo II (dos 
crimes contra a segurança individual) que "aquele que ajudar alguém a suicidarse, ou fornecer-lhe meios para esse fim com conhecimento de causa" seria punido à "pena de prisão por dous a seis annos".

Seguindo a tradição, o Código Penal de 1890 tipificou a indução ou auxílio ao suicídio, prevendo em seu artigo 299 que quem "induzir, ou ajudar alguém a suicidar-se, ou para esse fim fornecer-lhe meios, com conhecimento de causa" seria punido de dous a quatro anos de prisão cellular.

Por fim, em 1940, foi promulgado o atual Código Penal brasileiro que deu origem ao artigo 122, tendo sido diretamente influenciado pelo Código Penal italiano na redação do dispositivo.

Isso porque, em seu artigo 580, é previsto pelo Código Penal italiano que "quem determina outrem ao suicídio, ou reforça o propósito de outrem a suicidarse, ou auxilia de qualquer modo a execução, é punido, se o suicídio se consuma, com a reclusão de cinco a doze anos.”. Já o artigo 583 do mesmo diploma legal prevê que, se o suicídio não se consuma, é punido com a reclusão de um a cinco anos, sempre que da tentativa de suicídio resulte uma lesão pessoal grave ou gravíssima. As penas são aumentadas (artigo 64) se a pessoa instigada, excitada ou ajudada se encontra em uma das condições indicadas nos números $1^{\circ}$ e $2^{\circ}$ do artigo precedente. Contudo, se a pessoa referida é menor de quatorze anos ou privada da capacidade de entender ou querer, aplicam-se as disposições relativas ao homicídio (artigos 575 e 577). ${ }^{16}$

Atualmente, a abreviação da morte com auxílio de terceiros é permitida legalmente em 03 (três) países, quais sejam, Holanda, Bélgica e Luxemburgo, e em alguns estados dos Estados Unidos.

Nota-se, portanto, que apenas a Holanda, a Bélgica e Luxemburgo possuem legislações que autorizam a prática da eutanásia ativa, punida nos demais países como crime de homicídio, seja ele simples, privilegiado, ou crime próprio. Quanto

\footnotetext{
${ }^{16}$ REGIS PRADO, Luiz. Tratado de Direito Penal Brasileiro: Parte Especial Arts. 121 ao 183. 2a ed. [S.1.]:

Rt - Revista Dos Tribunais, 2017. 108 p.
} 
ao suicídio assistido, é autorizado na Holanda, Luxemburgo e determinados estados dos Estados Unidos, não tendo sido recepcionado pela legislação belga.

Já o Japão, a Colômbia e o Uruguai, apesar de ainda punirem legalmente tanto a eutanásia ativa quanto o suicídio assistido, passam por um movimento despenalizador advindo de seus tribunais.

A seguir são expostos detalhadamente os procedimentos internos de cada um dos países que autoriza a prática, bem como a apresentação de determinados. Ressalte-se, contudo, que o tópico em epígrafe não é exauriente, sendo certo que é possível verificar a existência de outros países em que a morte assistida fora regulamentada de alguma forma, mas que não foram abordados a seguir.

\section{1 - HOLANDA}

Na Holanda, em 2002, foi promulgada a chamada "Lei sobre a cessão da vida a pedido e o suicídio assistido" 17 , que autoriza tanto a participação de outrem no ato suicida - fornecendo medicamentos ao suicida, por exemplo - quanto à própria execução - injeção letal por terceiros.

A aludida lei foi responsável por prever situações em que o médico estaria acobertado por excludentes de ilicitude, sendo certo que, ausentes as circunstâncias previstas, a conduta continua sendo punida pelo Código Penal.

Apesar de a referida Lei só ter sido promulgada em 2002, a Suprema Corte Holandesa, em 1984, decidiu que um médico que abreviasse a vida de um paciente poderia, em determinadas circunstancias, invocar a defesa de necessidade para justificar sua ação ${ }^{18}$, oportunidade em que foram consolidados jurisprudencialmente os critérios considerados como autorizadores para a prática da Eutanásia.

A aprovação da lei encontrou resistência por parte dos parlamentares religiosos, tendo estabelecido, em seu artigo $2^{\circ}, \S 1^{\circ}$, os seguintes requisitos quando

\footnotetext{
${ }^{17}$ Pessini, Leocir.Op. Cit. p. 115

${ }^{18}$ Pessini, Leocir.Op. Cit. p. 116
} 
da sua entrada em vigor: a solicitação deve ser voluntária e o paciente deve ter refletido longamente sobre ela, o médico deve ter certeza quanto ao caráter insuportável e insuperável do sofrimento do paciente, bem como que de que não há nenhuma outra solução razoável para o seu alívio. Todas as informações relativas à situação do paciente devem ter sido informadas a ele, e o médico deverá buscar apoio a sua decisão por um colega independente. ${ }^{19}$

Há, ainda, regras procedimentais que deverão ser observadas pós- morte, sendo elas a comunicação motivada ao Instituto Médico Legal, de modo que uma Comissão especializada verifique se todos os requisitos foram respeitados segundo a Lei relativa ao Término da Vida sob Solicitação e Suicídio Assistido. Se todos os requisitos legais forem devidamente respeitados, o médico não será punido criminalmente. $^{20}$

Ressalte-se, contudo, que ainda assim não é possível verificar o direito à autodeterminação em sede de eutanásia, já que a decisão de atender ou-não a uma solicitação em tal sentido permanece a cargo do médico. Ou seja, ao médico é conferido o direito de negar a solicitação se assim entender, cabendo a ele a decisão final.

No que tange à faixa etária do paciente, três diferentes diretrizes devem ser observadas a depender da idade. Os pacientes que têm 16 (dezesseis) anos ou mais e já não podem expressar sua vontade, devem ter subscrito uma declaração a autorizando. Aqueles que têm de 16 (dezesseis) a 18 (dezoito) anos de idade e estiverem em condição de apreciar de maneira razoável seus interesses, devem ter a participação dos responsáveis na tomada de decisão. E, por fim, para aqueles que têm entre 12 (doze) e 16 (dezesseis) anos e possuírem compreensão razoável de seus interesses, os pais devem ter concordado com a realização do procedimento. Percebe-se, portanto, que a partir dos 16 (dezesseis) anos não é preciso a autorização por parte dos pais ou tutores, apenas que tenham participado do processo.

\footnotetext{
${ }^{19}$ Pessini, Leocir.Op. Cit. p. 117

${ }^{20}$ JOSÉ MANUEL, Pinto; TERESA, Montalvão da Cunha. Eutanásia e Suicídio Assistido. 2016
} 


\section{2 - BÉLGICA}

A Bélgica foi o segundo país à regulamentar e autorizar a prática da morte assistida, tendo sido aprovada, em 28 de maio de 2002, a chamada "Lei relativa à Eutanásia" ${ }^{21}$.De acordo com a legislação, entende-se por eutanásia o ato, praticado por terceiros, que faz cessar a vida de uma pessoa a seu pedido ${ }^{22}$.

Para ser considerada legal, é necessário que sua prática se dê sempre por um médico, sendo certo que não é permitido ao próprio paciente, ou a um terceiro, que administre a medicação. O médico deve estar assegurado de que o paciente é adulto ou menor emancipado, devendo ter plena capacidade e consciência na época de seu pedido, que deve ser feito de forma voluntária, ponderada, reiterada e sem qualquer influência externa. O paciente deve, ainda, se encontrar em condição médica irremediável e se queixar de sofrimento físico ou mental constante e insuportável que não pode ser diminuído, sendo resultante de condição acidental ou doença grave e incurável. ${ }^{23}$

Ainda em relação ao pedido de autorização, é previsto pela lei que deve obedecer a forma escrita, e o médico precisará apresentar para o paciente todas as alternativas e métodos paliativos para o seu tratamento.

Em 2014, a lei foi alterada a fim de que o direito à eutanásia fosse garantido também aos menores de idade. $\mathrm{O}$ artigo $3^{\circ}$ da mesma lei, segundo a nova redação, passou a prever, além dos requisitos necessários para que a prática da eutanásia seja considerada legal, que o paciente seja maior de idade ou menor emancipado capaz ou ainda menor de idade dotado de capacidade de discernimento ${ }^{24}$ e esteja consciente no momento do pedido. A lei, contudo, não indicou quaisquer diretrizes acerca do que seria considerado discernimento, apesar de o texto legal impor que,

\footnotetext{
${ }^{21}$ JOSÉ MANUEL, Pinto; TERESA, Montalvão da Cunha. Eutanásia e Suicídio Assistido. 2016

${ }^{22}$ Pessini, Leocir.Op. Cit. p. 124

${ }^{23}$ Pessini, Leocir. Op. Cit. p.125

${ }^{24}$ JOSÉ MANUEL, Pinto; TERESA, Montalvão da Cunha. Eutanásia e Suicídio Assistido. 2016
} 
além do médico responsável, também um psiquiatra infantil avalie a maturidade do paciente.

A lei ainda prevê determinadas condutas que deverão ser adotadas pelo médico antes da prática da eutanásia, quais sejam, informar ao paciente sobre seu estado de saúde e sua expectativa de vida, estar seguro quanto à persistência do sofrimento do paciente, confirmar em espaços de tempo a sua vontade em ser submetido à eutanásia, consultar outro médico quanto ao caráter incurável da doença do paciente, consultar um pediatra e um psicólogo quando o paciente for menor de idade não emancipado, discutir o pedido de eutanásia junto à equipe médica responsável pelo tratamento do paciente, discutir, se esta for a vontade do paciente, o pedido com as pessoas próximas que tiverem sido designadas por ele, e, por fim, se assegurar de que o paciente teve a oportunidade de discutir seu pedido com as pessoas designadas. ${ }^{25}$

Assim como na Holanda, foi criada comissão especial com o fim de verificar, a posteriori, se todos os procedimentos foram seguidos corretamente pelo médico. Em caso de irregularidade ou suspeita, a comissão deve elaborar um dossier para ser enviado aos órgãos com competência para instaurar eventuais procedimentos criminais. ${ }^{26}$

Estando ausente qualquer um dos pressupostos, a conduta constitui crime de homicídio simples, punido pelo Código Penal. Sendo assumida a forma de auxílio ao suicídio, e, não estando presentes as condições elencadas pela legislação, a conduta poderá por punida como falta de assistência à pessoa em perigo. ${ }^{27}$

\footnotetext{
${ }^{25}$ Pessini, Leocir. Op. Cit. p. 125

${ }^{26}$ JOSÉ MANUEL, Pinto; TERESA, Montalvão da Cunha. Eutanásia e Suicídio Assistido. 2016

${ }^{27}$ Os artigos pertinentes que cobrem estas situações são os artigos $393 .^{\circ}$ (sobre o homicídio), 397. ${ }^{\circ}$ (sobre envenenamento), $422 .^{\circ}$ e $423 .^{\circ}$ (sobre situações de omissão de assistência a pessoas em perigo) do Código Penal.
} 


\section{3 - ESTADOS UNIDOS}

Desde os anos 90, todos os estados norte-americanos já reconhecem alguma forma de diretriz antecipada da morte, seja pelos "testamentos de vida", documentos nos quais se estipula que determinados tratamentos médicos não deverão ser utilizados à manutenção da vida, seja pelas “procurações para a tomada de decisões em questões médicas", assinadas por aqueles que outorgam a outrem o poder de tomar decisões em seu nome quando não tiverem mais essa capacidade. $^{28}$

Atualmente, verifica-se que, em âmbito federal, tanto a eutanásia ativa quanto o suicídio assistido são punidos criminalmente. No entanto, tendo em vista que o sistema de governo norte-americano prevê a competência estatal para legislar e aprovar leis que irão vigorar dentro de seus territórios, determinados estados já autorizam a prática do suicídio assistido.

Com efeito, a eutanásia ativa não foi descriminalizada por nenhuma legislação local, sendo certo que ainda constitui o crime de homicídio. Tendo sido descriminalizado tão somente a prática do suicídio assistido, em todos os casos quem deverá administrar a medicação será o próprio paciente.

O estado de Oregon foi o primeiro a autorizar a prática, tendo em 1997 aprovado, por meio de um referendo que contou com $51 \%$ dos votos a favor, que o paciente, maior de 18 (dezoito) anos, residente em Oregon, acometido por doença terminal com expectativa de no máximo 06 (seis) meses de vida e capaz de tomar decisões, requeira medicação capaz de leva-lo a morte. Percebe-se, portanto, se tratar da prática de suicídio assistido, vez que a medicação é administrada pelo próprio paciente. ${ }^{29}$

Além de tais exigências, é preciso que, após a primeira solicitação feita de forma oral pelo paciente, se aguarde 15 (quinze) dias para colher nova declaração, devendo esta ultima ser reduzida a termo. Após a colheita da declaração feita por

\footnotetext{
${ }^{28}$ JOSÉ MANUEL, Pinto; TERESA, Montalvão da Cunha. Eutanásia e Suicídio Assistido. 2016

${ }^{29}$ Pessini, Leocir. Op. Cit. 128
} 
escrito, o paciente deverá aguardar 48h para ir à farmácia buscar a medicação prescrita.

Além disso, é previsto pela lei que apenas aqueles que cumprirem os exatos termos estabelecidos pela legislação estarão a salvo da persecução penal, bem como que médicos e sistemas de saúde não estão obrigados a participar.

Os demais estados que autorizam a prática são Washington, DC, Montana, Vermont, Califórnia, Havaí. À exceção do estado de Montana, que aprovou a prática por via jurisprudencial, os outros estados possuem legislação específica acerca do tema.

Em linhas gerais, lidam de forma semelhante, contando com pequenas diferenças a nível procedimental. Todos têm como requisitos que o paciente seja residente do estado, seja maior de 18 (dezoito) anos, possua 06 (seis) meses ou menos de expectativa de vida, tenha capacidade e faça ao menos dois requerimentos com lapso temporal de no mínimo 15 (quinze) dias.

\section{4 - LUXEMBURGO}

Em Luxemburgo desde 2009, passou a vigorar lei regulamentando tanto a eutanásia ativa, quanto o suicídio $\operatorname{assistido~}^{30}$. Foi a partir dela que se incluiu ao Código Penal disposição esclarecendo que não estará sujeito às sanções penais o médico que atende ao pedido do paciente no sentido de ser submetido à eutanásia, ou sejam fornecidos medicamentos para que abrevie por si próprio sua morte.

\footnotetext{
${ }^{30}$ No texto original: “A46 : Loi du 16 mars 2009 relative aux soins palliatifs, à la directive anticipée et à l'accompagnement en fin de vie et modifiant: 1. le Code de la sécurité sociale; 2. la loi modifiée du 16 avril 1979 fixant le statut général des fonctionnaires de l'Etat; 3. la loi modifiée du 24 décembre 1985 fixant le statut général des fonctionnaires communaux; 4. le Code du travail." Disponível em < http://legilux.public.lu/eli/etat/leg/loi/2009/03/16/n1/jo >
} 
Entende-se por "eutanásia", segundo a legislação, o ato do médico que intencionalmente põe termo à vida de uma pessoa a seu pedido expresso e voluntário. Por sua vez, "suicídio assistido" é considerado o ato do médico que auxilia outra pessoa a pôr termo a própria vida, sob seu pedido expresso e voluntário.

Determinadas condições devem ser observadas a fim de que a conduta praticada pelo médico não seja punível, tais como a maioridade e capacidade do paciente no momento do pedido, que deve ter sido formulado de forma voluntária e refletida, sendo repetido, se necessário. Além disso, o paciente deve estar em situação médica que não expire esperanças de melhora, e que o confira sofrimento físico ou psicológico constante e insuportável. Por fim, o pedido formulado deve obedecer à forma escrita.

Tendo sido preenchidos os pressupostos supramencionados, o médico ainda deverá respeitar condições de forma e procedimento, conferindo ao paciente todas as informações cabíveis acerca do seu estado de saúde e sua expectativa de vida, discutindo e ponderando todas as possibilidades terapêuticas ainda possíveis. Ademais, deverá estar seguro quanto à persistência do sofrimento físico ou mental do paciente e da sua vontade, que deve ter sido expressa reiteradamente em entrevistas realizadas em espaços de tempo razoáveis. Outro médico competente, sendo informado acerca da motivação da consulta, deverá examinar o paciente e reforçar o caráter grave e incurável da doença. O requerimento deve ainda ser discutido com a equipe médica responsável por assegurar os cuidados regulares ao paciente.

O paciente, quando da formalização de seu pedido, deverá designar pessoa de sua confiança, que discutirá com o médico o requerimento formulado. Outrossim, o médico deverá estar certificado quanto à oportunidade do paciente de dialogar acerca do seu requerimento com pessoas que entender. Por fim, o médico deverá realizar consulta junto à Comissão Nacional de Controle e Avaliação quanto a eventuais registros de disposições de fim de vida em nome do paciente. 
O pedido poderá ser revogado a todo momento, de modo que o documento escrito em que se formalizou o requerimento será restituído ao paciente.

Aquele que não possuir condições de manifestar a sua vontade quando do momento pretérito à morte, poderá deixar consignado por escrito, em disposições de fim de vida, obrigatoriamente datadas e assinadas, as circunstancias e condições nas quais pretende se submeter à eutanásia. Evidentemente, além de todos os pressupostos mencionados anteriormente, o estado de inconsciência experimentado pelo paciente deverá ser permanente.

Por fim, impende destacar que, à semelhança do que ocorre em outros ordenamentos jurídicos, o artigo $15^{\circ}$ da referida lei assegura ao médico a objeção de consciência, determinando que nenhum médico é obrigado a praticar qualquer um dos atos tratados pela lei. Da mesma forma, nenhuma outra pessoa será obrigada a participar do ato. No entanto, recusando a prática, o médico deverá informar o paciente ou pessoa de sua confiança acerca das razões que o levaram a recusar.

\section{5 - JAPÃO}

No Japão, tanto a eutanásia ativa quanto o suicídio assistido constituem crimes, previstos pelo Código Penal em seus artigos 199 e 202. ${ }^{31}$ No primeiro, verifica-se a punição pelo chamado crime de homicídio simples e o segundo um tipo de crime que comportaria a figura do suicídio assistido ou do homicídio a pedido da vítima.

Em que pese aquele que pratique a eutanásia ativa esteja usualmente incurso nas penas do artigo 202, vez que mata determinado indivíduo a seu pedido, em determinadas situações a prática é punida como o crime do artigo 199.

À semelhança do que ocorre na legislação brasileira, o elemento diferenciador entre as duas condutas é justamente o consentimento do suicida. Não

\footnotetext{
${ }^{31}$ JOSÉ MANUEL, Pinto; TERESA, Montalvão da Cunha. Eutanásia e Suicídio Assistido. 2016.
} 
sendo possível verificar com clareza o consentimento da vítima, o agente é punido nos termos do artigo 199.

Ressalte-se, contudo, que, muito embora não haja qualquer previsão legal quanto à descriminalização das referidas condutas, os tribunais vêm tolerando a prática.

Foram consolidadas jurisprudencialmente determinadas condições para que a conduta não fosse considerada criminosa, sendo elas a necessidade de o paciente sofrer de insuportável dor física, a morte ser inevitável e estar próxima, o consentimento do paciente, bem como o esgotamento de todos os outros tratamentos ao alivio do sofrimento.

Dessa forma, sendo a conduta tipificada pelo artigo 202, bem como verificadas todas as condições estabelecidas jurisprudencialmente, são consideráveis as chances de o agente não ser punido pelos tribunais.

\section{6 - COLÔMBIA}

É previsto pelo artigo $106^{\circ}$ do Código Penal que "aquele que matar o outro por piedade, para pôr fim a intensos sofrimentos resultantes de lesão corporal ou doença grave e incurável, incorre a prisão de (01) um a (03) três anos"32.

Verifica-se, portanto, na legislação colombiana, a previsão de um crime específico para a eutanásia ativa, conhecido como "homicídio por piedade".

No entanto, a exemplo do que vem ocorrendo no Japão, é possível identificar um movimento advindo dos tribunais colombianos no sentido de isentar aqueles cometem o aludido crime de pena.

Para isto é preciso que o crime tenha se dado com o consentimento doo ofendido, bem como que este estivesse em fase terminal.

Por outro lado, em relação ao suicídio assistido, o $\mathrm{n}^{\circ} 1$ do $\operatorname{artigo} 107^{\circ}$ do Código Penal colombiano prevê que "aquele que eficazmente induz o outro a

\footnotetext{
${ }^{32}$ JOSÉ MANUEL, Pinto; TERESA, Montalvão da Cunha. Eutanásia e Suicídio Assistido. 2016.
} 
suicídio, ou the preste uma ajuda específica para sua realização, incorre em prisão de 02 (dois) a 06 (seis) anos. Quando a indução ou ajuda estiver dirigida a pôr fim a intensos sofrimentos provenientes de lesão corporal ou enfermidade grave e incurável, se incorre em prisão de 01 (um) a 02 (dois) anos". ${ }^{33}$

Muito embora os tribunais venham atuando positivamente apenas no que tange à figura do homicídio por piedade, da própria norma que prevê a indução ou ajuda ao suicídio, verifica-se uma atenuação considerável de pena quando o agente age com fins humanitários.

\section{1- URUGUAI}

O Uruguai é considerado pioneiro no movimento de despenalização da conduta pela via judicial. É previsto pelo artigo $37^{\circ}$ do Código Penal uruguaio que "Os juízes têm a faculdade de exonerar de castigo o sujeito de antecedentes honráveis, autor de um homicídio, efetuado por motivos de piedade, mediante pedidos reiterados da vítima". ${ }^{34}$

Ou seja, o próprio texto legal concede ao judiciário a faculdade de, analisando o caso concreto, despenalizar o individuo que comete o crime conhecido como "homicídio piedoso".

Não bastasse o artigo $37^{\circ}$, é previsto ainda pelo artigo 127 do mesmo diploma legal, intitulado como "do perdão judicial”, que, "os juízes podem fazer o uso dessa faculdade nos casos previstos pelos artigos 36, 37, 39, 40 e 45 do Código".

\footnotetext{
${ }^{33}$ No texto original: "El que eficazmente induzca a otro al suicidio, o le preste una ayuda efectiva para su realización, incurrirá en prisión de dos (2) a seis (6) años. Cuando la inducción o ayuda esté dirigida a poner fin a intensos sufrimientos provenientes de lesión corporal o enfermedad grave e incurable, se incurrirá en prisión de uno (1) a dos (2) años.”

${ }^{34}$ No texto original: "Los Jueces tiene la facultad de exonerar de castigo al sujeto de antecedentes honorables, autor de un homicidio, efectuado por móviles de piedad, mediante súplicas reiteradas de la víctima".
} 
Para que o agente seja considerado como isento de pena pelo tribunal, determinados requisitos devem estar presentes, tais como não ter antecedentes criminais, o crime ter sido praticado por motivo piedoso e a vítima ter feito reiterados pedidos no sentido de morrer.

No entanto, em relação ao suicídio assistido, o artigo $315^{\circ}$ do Código Penal uruguaio não confere o mesmo tratamento, conferindo-se ao agente a pena de 06 (seis) meses a 06 (seis) anos, se, determinando ou ajudando alguém a se matar, a morte vier a acontecer.

A pena pode ser ainda aumentada para 12 (doze) anos, se a vítima é menos de 18 (dezoito) anos, tiver qualquer das suas faculdades mentais reduzidas em razão de doença mental ou pelo uso de substâncias entorpecentes ou alcóolicas.

\section{2 - CANADÁ}

O Canadá sofreu recentíssima alteração legislativa quanto ao tema ora em apreço. A Suprema Corte canadense, em fevereiro de 2015, no caso Carter vs. Canadá, determinou que o parlamento canadense tinha até junho de $2016 \mathrm{p}^{-\cdots-}$ alterar a legislação relativa à morte assistida.

No prazo estabelecido, o parlamento aprovou lei que altera o Código Penal canadense autorizando tanto a prática da eutanásia ativa ${ }^{35}$, quanto do suicídio assistido $^{36}$. Necessário destacar, contudo, que apesar da alteração legislativa a nível federal, cada província canadense possui determinado procedimento a ser seguido, não havendo uniformização nesse sentido.

São requisitos para a autorização da realização do procedimento residir no Canadá, ser maior de 18 (dezoito) anos, mentalmente competente para discernir, possuir uma dolorosa e irremediável condição de saúde, requerer de forma voluntária e consentir após receber todas as informações pertinentes.

\footnotetext{
${ }^{35}$ Originariamente chamada de physician-administered euthanasia (PAE)

${ }^{36}$ Originariamente chamado de physician-assisted suicide (PAS)
} 
Quanto à dolorosa e irremediável condição de saúde, entende-se por doença grave, em estágio avançado e irreversível, experimentar insuportáveis sofrimentos físicos ou mentais que não possam ser aliviados de outras formas, e ter a morte natural como previsível. Ressalte-se, contudo, que a condição de saúde do paciente não precisa estar em fase terminal.

O consentimento para que se pratique o procedimento não pode ser dado com muita antecedência, como seria o caso, por exemplo, de pessoas acometidas por Alzheimer, que optariam previamente pela morte quando a doença atingisse estágios avançados. É preciso que a capacidade para consentir esteja presente do primeiro pedido ao último momento antes da morte. Além disso, deve ser reiterado de forma expressa e pode ser revogado a qualquer tempo.

Quanto às doenças mentais, a legislação canadense não descarta a possibilidade de serem motivadoras da morte assistida, desde que os requisitos supramencionados sejam respeitados.

\section{Capítulo 03 - 0 PRINCÍPIO DA DIGNIDADE DA PESSOA HUMANA E A MORTE ASSISTIDA}

O debate acerca da morte assistida gira entorno, em muitos momentos, da temática quanto à aplicabilidade, conceito e alcances do princípio da dignidade da pessoa humana, consagrado pela Constituição Federal de 1988 em seu artigo $1^{\circ}$, inciso III.

Muito embora o aludido princípio ocupe posição eminente na esmagadora maioria dos ordenamentos jurídicos, sendo considerado o horizonte ético da humanidade contemporânea ${ }^{37}$, sua aplicabilidade vem encontrando dificuldades quando se trata de casos concretos. Seu caráter elástico permite que cada um conceba e invoque a sua própria concepção de dignidade, não sendo possível

\footnotetext{
${ }^{37}$ Pessini, Leocir. Op. Cit. p. 134
} 
identificarmos uma compreensão objetiva e precisa quanto ao seu conceito e ao que busca proteger na prática:

"No plano abstrato, a dignidade traz em si grande força moral e jurídica, capaz de seduzir o espírito e angariar adesão quase unânime. Tal fato, todavia, não minimiza a circunstância de que se trata de uma ideia polissêmica, que funciona, de certa maneira, como um espelho: cada um projeta nela a sua própria imagem de dignidade."${ }^{.38}$

Não por outro motivo, frequentemente lados rivais de determinada discussão, como é o caso da temática em apreço, são vistos invocando o princípio da dignidade da pessoa humana como fundamento para sua argumentação. ${ }^{39}$ Opositores e defensores da morte assistida utilizam a dignidade como embasamento.

Esse capítulo possui como propósito analisar a trajetória, contornos e alcances da dignidade humana enquanto princípio, sua repercussão no direito à vida, e o papel da autonomia existencial como fundamento deste princípio.

\section{1 - O PRINCÍPIO DA DIGNIDADE DA PESSOA HUMANA: CONTORNOS E ALCANCE}

É ao final da Segunda Guerra mundial, em 1945, que o princípio da dignidade da pessoa humana ganha expressão e passa a ser assegurado por diversos ordenamentos jurídicos, sendo mencionado em incontáveis tratados e declarações internacionais. A Declaração Universal dos Direitos Humanos proclamada pelas Nações Unidas em 10 de dezembro de 1948 afirma em seu preâmbulo: "O reconhecimento da dignidade inerente a todos os membros da família humana e de seus direitos iguais e inalienáveis constitui o fundamento da liberdade, da justiça e da paz no mundo".

Está consagrado em 149 (cento e quarenta e nove) das 194 (cento e noventa e quatro) constituições nacionais que hoje estão em vigor. Ainda nos países que

\footnotetext{
${ }^{38}$ BARROSO, Luis Roberto; MARTEL,Letícia de Campos Velho. Op. Cit. p. 15

${ }^{39}$ BARROSO, Luis Roberto; MARTEL, Letícia de Campos Velho. Op. Cit. p.15
} 
não a mencionam expressamente, como na França e nos Estados Unidos, sua eficácia é reconhecida (SARMENTO, 2016).

Representa, ao menos no mundo ocidental, a estrutura basilar do discurso ético $^{40}$, invocada, muitas vezes, em face do poder opressivo estatal exercido em relação aos indivíduos.

$\mathrm{Na}$ Constituição Federal brasileira ela encontra lugar no $\operatorname{artigo~} 1^{\circ}$, inciso III, sendo considerada um dos fundamentos do estado democrático de direito. É a partir dela que se fará a interpretação de toda a legislação, servindo verdadeiramente como vetor e fonte de todos os demais direitos. Seja pela doutrina, seja pela jurisprudência, a dignidade da pessoa humana é tida como "valor supremo da democracia" 41.

Nas palavras de Daniel Sarmento (2016, p. 312),

"essa importância atribuída à dignidade da pessoa humana no Brasil e no constitucionalismo global deve ser saudada como sinal de avanço civilizatório. Afinal, trata-se de princípio profundamente humanista, baseado na valorização da pessoa e comprometido com a garantia dos seus direitos básicos contra todas as formas de injustiça e opressão. Portanto, é promissor que tal princípio tenha passado a desempenhar papel de destaque nos ordenamentos jurídicos contemporâneos.".

Necessário mencionar, contudo, a dificuldade em se obter uma definição satisfatória sobre tal conceito. A conceituação do princípio esbarra em contornos extremamente vagos e porosos, além de possuir natureza necessariamente polissêmica. $^{42}$

Há quem diga que é justamente o alcance obtido pelo conceito de dignidade, tido como um argumento de maior importância, quase como uma "carta trunfo", que justifica, em parte, as suas ambiguidades e permanência em discursos completamente contraditórios.

\footnotetext{
${ }^{40}$ BARROSO, Luis Roberto; MARTEL,Letícia de Campos Velho. Op. Cit. p. 16

${ }^{41}$ SILVA, José Afonso da. A dignidade da pessoa humana como valor supremo da democracia. Poder constituinte e poder popular. São Paulo: Malheiros, 2000. p. 144-149.

${ }^{42}$ BARROSO, Luis Roberto; MARTEL,Letícia de Campos Velho. Op. Cit. p. 04
} 
A bem da verdade, por se tratar de conceito jurídico-normativo de categoria axiológica aberta, jamais poderá ser definido de forma fixa, uma vez que tal conceito está em constante processo de construção jurídico-social. Além disso, uma definição sólida e imutável de dignidade não se harmonizaria com os demais princípios e valores propugnados pela Constituição Federal. ${ }^{43}$

Apesar da dificuldade em se estabelecer sua definição e significado, é possível identificar inúmeros momentos em que a dignidade é frontalmente agredida. Se releva mais fácil, portanto, estabelecer o que a dignidade não é do que o que ela realmente é.

Nesse cenário permeado pela inexatidão e imprecisão, a doutrina e a jurisprudência trataram de firmar determinados limites basilares do seu conceito e conteúdo, muito embora permaneça demandando concretização e delimitação.

Além disso, a própria norma contém elementos capazes de nortear a atuação do intérprete, fornecendo um início de significação, que deverá ser complementado de acordo com as circunstâncias do caso concreto. Sintetizando o exposto, afirma Luis Roberto Barroso:

"O intérprete precisa fazer a valoração de fatores objetivos e subjetivos presentes na realidade fática, de modo a definir o sentido e o alcance da norma. Como a solução não se encontra integralmente no enunciado normativo, sua função não poderá limitar-se à revelação do que lá se contém; ele terá de ir além, integrando o comando normativo com a sua própria avaliação" 44

Muito embora ela não dependa de qualquer previsão normativa para existir, vez que atributo inerente a toda e qualquer pessoa humana, entende-se que o Direito possui a função de protege-la e promove-la.

Isso porque, a dignidade como fundamento da República, não apenas impõe limite à atuação estatal, impedindo que o poder público viole a dignidade dos indivíduos, como também significa que o Estado deverá ter, como meta permanente, a promoção concreta de uma vida digna para todos os cidadãos. $\mathrm{O}$

\footnotetext{
${ }^{43}$ Sarlet, Ingo. Op. Cit. p. 121

${ }^{44}$ BARROSO, Luis Roberto. Neoconstitucionalismo e constitucionalização do direito (o triunfo tardio do direito constitucional no Brasil). Revista Eletrônica sobre a Reforma do Estado -RERE, n. 09, 2007, p. 13
} 
princípio da dignidade da pessoa humana impõe dever de proteção ao Estado e aos particulares. $\mathrm{O}$ dever de proteção abrange inclusive a proteção da pessoa contra si mesma, autorizando o Estado a intervir nos casos em que o indivíduo atente contra a sua própria dignidade.

Nesse sentido, apesar de a dignidade não ser fruto da criação jurídica, mas sim valor que antecede o direito, é bem verdade que a busca por uma definição que delimite seus contornos e seu alcance é de suma importância para que se constate e coíba eventuais violações.

De início, pode-se afirmar que a dignidade da pessoa humana, entendida como qualidade intrínseca do indivíduo, é irrenunciável e inalienável. É compreendida como integrante da própria condição humana, não podendo ser concedida, criada, tampouco retirada.

Além disso, a dignidade, em seu alcance e magnitude, não varia de acordo com o caso concreto, de modo que todos que são reconhecidos como seres humanos são iguais em dignidade. Ou seja, pode se tratar de criminoso contumaz ou de alguém que possua reputação ilibada, a dignidade não será aplicada de forma diferente para um ou para o outro.

Por sua vez, o que faz todos serem reconhecidos como seres humanos e, portanto, iguais em direito e dignidade, é justamente a racionalidade e a consciência.

Essa construção da concepção de dignidade a partir da natureza racional do ser humano encontra raízes no pensamento de Immanuel Kant, que afirmou ser a autonomia da vontade, entendida como a faculdade de determinar a si mesmo e agir em conformidade com a representação de certas leis, um atributo apenas encontrado nos seres racionais (SARLET, 2006, p.127).

Ainda de acordo com os postulados kantianos, o ser humano existe como um fim em si mesmo, não podendo servir de instrumento para atingir determinada finalidade. Com efeito, a dignidade opera como impedimento a toda e qualquer 
coisificação e instrumentalização do ser humano, ainda que dirigida contra ele próprio $^{45}$.

\subsection{1 - A DIGNIDADE DA PESSOA HUMANA COMO AUTONOMIA}

Até o século XIX, a autonomia privada se limitava a tutelar a esfera patrimonial do indivíduo. Concebida sob a influência do liberalismo jurídico, a autonomia representava a liberdade absoluta e individual que garantia, ao indivíduo, a possibilidade de negociar seus bens de forma livre. Essa formulação de autonomia desconsiderava o sujeito em sua singularidade, ignorando todo o leque de variáveis que conduzem o indivíduo a viver de acordo com o projeto de vida que desenhou para si mesmo.

A autonomia privada como se concebe atualmente não se confunde com a autonomia da vontade, que era própria ao Direito das Obrigações e Contratos, dizendo respeito, principalmente, a negócios jurídicos de conteúdo patrimonial, muito comum em ordenamentos jurídicos voltados mais para o ter do que para o ser. Ademais, o pano de fundo era a concepção formal da liberdade dos agentes, pouco importando a realidade concreta marcada por sérias desigualdades materiais. A autonomia da vontade, em linguagem universal, era o espelho de interesses do homem branco, burguês e proprietário (SARMENTO, p. 141, 2016).

A partir do momento que a dignidade da pessoa humana é alocada para o vértice do ordenamento jurídico, devendo ser respeitada e promovida, inclusive nas relações circunscritas ao âmbito privado, essa antiga concepção de autonomia deixou de encontrar amparo no direito.

A dignidade impõe proteção plena em relação a todos os aspectos da pessoa. No entanto, conforme sustenta Ingo Sarlet (2016, p. 45), a proteção nuclear da dignidade recai sobre a autonomia do indivíduo, e seu direito de autodeterminação. Ou seja, o elemento basilar de proteção da dignidade se dá em relação à

\footnotetext{
${ }^{45}$ SARLET, Ingo op. Cit. p. 33
} 
possibilidade de o indivíduo desenvolver livremente sua personalidade de forma autônoma, de construir sua vida de acordo com seu próprio projeto de vida.

Nesse sentido, segundo Daniel Sarmento (2016, p. 420), a ideia de que as pessoas têm o direito de formular os seus próprios planos de vida, seus projetos existenciais, a partir das suas próprias compreensões do que seja uma "vida boa" é a base do respeito à autonomia privada.

Ainda segundo o autor, o único impedimento ao indivíduo para seguir seus projetos, seria a lesão a direitos de terceiros. Ausente essa barreira, o sujeito é livre para se autodeterminar, por mais que desafie tradições e costumes enraizados ou desagradem as maiorias sociais. ${ }^{46}$

Segundo Luís Roberto Barroso, 04 (quatro) aspectos essenciais podem ser destacados da visão da autonomia como justificação para os direitos humanos e fundamentais, sendo eles a capacidade de autodeterminação, as condições para o exercício da autodeterminação, a universalidade e a inerência da dignidade ao ser humano. ${ }^{47}$

A capacidade de autodeterminação implica em conferir ao indivíduo o poder de realizar as escolhas morais relevantes, devendo assumir posteriormente a responsabilidade pelas decisões tomadas e as consequências que dela foram oriundas. Nessa perspectiva, o sujeito tem o direito de decidir os rumos da própria vida e de desenvolver livremente a própria personalidade, fazendo escolhas existenciais desde que não violem direitos de terceiros.

Já as condições para o exercício da autodeterminação, explica o autor, estão ligadas à disposição de meios adequados para que essa liberdade que se pretende conferir ao indivíduo possa ser real e de fato exercida. É preciso que estejam asseguradas mínimas condições econômicas, educacionais e psicofísicas para que um ser humano possa traçar e concretizar seus planos de vida.

Por fim, a universalidade e a inerência estão ligados entre si. Uma vez que a dignidade possui caráter inerente e intrínseco a todo ser humano, se faz

\footnotetext{
${ }^{46}$ SARMENTO, Daniel. Op. Cit. p. 146

${ }^{47}$ BARROSO, Luis Roberto; MARTEL,Letícia de Campos Velho. Op. Cit. p. 32
} 
necessário que seja respeitada e promovida de modo universal. Não importa qual seja a condição nacional, cultural, religiosa ou étnica do indivíduo, a dignidade deverá ser reconhecida. Em síntese, não há que se falar em pessoas mais ou menos dignas.

Em síntese, a expressão da dignidade da pessoa humana enquanto autonomia valoriza a individualidade do sujeito, bem como a sua liberdade e seus direitos fundamentais. No entanto, não se pode olvidar que a dignidade enquanto autonomia não deve se dar de forma ilimitada e incondicional.

Fato é que o indivíduo não está sozinho no mundo, de modo que é preciso a harmonização de projetos de vida divergentes, evitando-se que direitos fundamentais entrem em coalisão e que escolhas individuais produzam impactos sobre a sociedade como um todo.

\subsection{2 - A DIGNIDADE DA PESSOA HUMANA COMO HETERONOMIA}

A vida em sociedade clama em determinados momentos por valores que norteiem a existência individual não como um fim em si mesmo, mas enquanto parte do todo. Nessa perspectiva, princípios como bem comum, interesse público e moralidade são postos em prioridade em face das escolhas individuais.

Nesse contexto, a dignidade da pessoa humana é compreendida como uma força externa ao indivíduo, que deve ser regida segundo padrões civilizatórios vigentes. As escolhas individuais são limitadas mesmo quando não interfiram em direitos alheios.

Se do ponto de vista explorado no tópico anterior a dignidade tinha na liberdade seu núcleo principal, na visão ora abordada ela assume justamente a função contrária: frear a liberdade do indivíduo para dar conta de um bem maior.

Segundo essa perspectiva, a dignidade é um valor objetivo, que ultrapassa a esfera individual e pode ser violada mesmo quando o indivíduo não considere que está tendo a sua dignidade violada. 
Diversos casos concretos se tornaram conhecidos ao redor do mundo por considerarem a dignidade como heteronomia. É o caso, por exemplo, dos chamados peep shows. A corte que proferiu a decisão considerou um atentado à dignidade da pessoa humana a realização desse tipo de apresentação, vez que o indivíduo se coloca, como um objeto, a disposição de outra pessoa. Segundo o julgado, a voluntariedade na realização do show não fazia com que a dignidade da pessoa humana deixasse de ser violada, já que ao indivíduo não caberia supostamente aliená-la ou renunciá-la. ${ }^{48}$

A concepção da dignidade como heteronomia foi também explorada quando da interposição da ação civil pública em face da resolução do Conselho Federal de Medicina que regulamentava as diretivas antecipadas de vontade. Sustentou o Procurador subscritor da petição inicial, que nem os pacientes terminais, tampouco seus familiares, estariam dotados de capacidade para tomar decisões referentes aos tratamentos médicos que serão ou não realizados. Descartou, portanto, a concepção de dignidade enquanto autonomia, destituindo os indivíduos de seu poder de escolha e autodeterminação. Ainda segundo o membro do órgão ministerial, a escolha pela morte representaria uma fuga, a escolha pelo caminho mais fácil, denotando que, na sua visão, digno seria enfrentar a morte. ${ }^{49}$

Ressalte-se, contudo, que a restrição à autonomia individual é, em muitos momentos, justificada pela busca do bem para o sujeito, ou, ainda, para a preservação da sociedade.

No entanto, conforme apontou Daniel Sarmento (2016, p.196), compreender a dignidade humana como heteronomia possibilita de inúmeras formas o autoritarismo e o moralismo desnecessariamente. Ainda segundo o autor, dessa conclusão não necessariamente se resulta a autonomia absoluta, mas sim a conclusão de que a heteronomia não pode ser considerada componente da dignidade, já que esta se volta ao empoderamento da pessoa, rejeitando que seu comportamento seja forçado a se adequar em valores morais.

\footnotetext{
${ }^{48}$ BARROSO, Luis Roberto; MARTEL,Letícia de Campos Velho. Op. Cit. p. 22

${ }^{49}$ BRASIL. MINISTÉRIO PÚBLICO FEDERAL. ACP nº 2007.34.00.014809-3. Petição Inicial.
} 


\section{2 - MORTE ASSISTIDA NA CONSTITUIÇÃO FEDERAL DE 1988 - DIGNIDADE DA PESSOA HUMANA E DIREITO À VIDA}

Apresentadas as duas concepções acerca do conceito de dignidade da pessoa humana - se expressa como autonomia ou como heteronomia - pergunta-se: sob qual ótica a Constituição Federal de 1988 enxerga a dignidade da pessoa humana?

Em breve síntese, a dignidade enquanto autonomia privilegia a ampliação da liberdade humana, desde que não haja violações a direitos de terceiros e sejam asseguradas condições mínimas ao exercício da autodeterminação.

Por outro lado, aqueles que são filiados ao entendimento da dignidade como heteronomia, repousam seus olhares sobre a proteção de determinados valores sociais e do próprio indivíduo. Neste aspecto, a liberdade individual é restringida ainda que não interfira em direitos alheios.

Ainda que não se possa eleger, de forma excludente, uma das concepções de dignidade em face da outra, ao se tratar da Constituição Federal de 1988, é possível concluir pelo predomínio da ideia de dignidade enquanto autonomia. ${ }^{50}$

Historicamente, a Carta Magna foi promulgada em um contexto de ruptura com o modelo ditatorial intervencionista, marcando o início da reconstrução democrática do Brasil. ${ }^{51}$ Não por outro motivo, existe um cuidado especial com as liberdades individuais, que estão inseridas dentro de um considerável elenco de direito e garantias individuais.

Ressalte-se, nesse sentido, que as decisões e correntes doutrinárias que adotam a dignidade como heteronomia, fazem uso, em muitos momentos, de termos como "moral pública" e "bons costumes". Estas expressões, contudo, sequer são mencionadas na Constituição Federal de 1988. Já as expressões "interesse público" e "ordem pública", quando mencionados, não abarcam hipóteses que incluem a restrição a direitos fundamentais. Quando comparada com textos constitucionais anteriores, clarifica-se ainda mais a intenção do poder

\footnotetext{
${ }^{50}$ BARROSO, Luis Roberto; MARTEL,Letícia de Campos Velho. Op. Cit. 25

${ }^{51}$ BARROSO, Luis Roberto; MARTEL,Letícia de Campos Velho. Op. Cit. 26
} 
constituinte originário em romper com a lógica inspirada na imposição de uma moralidade social e unitária. ${ }^{52}$

Não se pretende, contudo, sustentar que a dignidade da pessoa humana seja princípio absoluto na ordem constitucional brasileira. A ela são impostos limites, podendo ser vista com certa relatividade em determinados momentos. ${ }^{53}$ Existe o reconhecimento pela Constituição da necessidade de compromisso com o bem de todos, a erradicação da pobreza e a solidariedade social. ${ }^{54}$ A existência de tais expressões no texto legal denota a preocupação com algo que vai além do indivíduo e da sua liberdade, isto é, com um bem comum. Não por outro motivo, existem normas constitucionais que impedem, por exemplo, o exercício de trabalhos forçados, a comercialização de órgãos e tecidos humanos, bem como a prática da tortura, por entender que tais práticas violariam a dignidade humana. Verifica-se, portanto, a existência de determinado consenso acerca de valores sociais e morais comuns.

Luís Roberto Barroso aduz (2010, p. 27), ainda, que, de acordo com a jurisprudência do Supremo Tribunal Federal, é possível identificar a preponderância da concepção de dignidade enquanto autonomia, sendo certo que certas formulações figuram como "consensos sobrepostos". São estes:

“a) correlação da fórmula do 'homem objeto', ou da não instrumentalização dos seres humanos, à liberdade humana e às garantias constitucionais da liberdade; b) manutenção da integridade física e moral dos indivíduos; c) proibição da tortura, da imposição de tratamento desumano ou degradante e da crueldade." ${ }^{.55}$

À vista do exposto, Daniel Sarmento (2016, p. 229) se manifesta no mesmo sentido, afirmando que a melhor leitura da dignidade é aquela que considera pessoas como agentes moais, que têm o direito de fazer as suas escolhas de vida, livres de amarras não só legais, como também econômias e culturais. Essa

\footnotetext{
52 BARROSO, Luis Roberto; MARTEL,Letícia de Campos Velho. Op. Cit. p 26

53 SARMENTO, Daniel. Op. Cit. p. 97

${ }^{54}$ BARROSO, Luis Roberto; MARTEL,Letícia de Campos Velho.Op. Cit. p. 26

${ }^{55}$ BARROSO, Luis Roberto; MARTEL,Letícia de Campos Velho. Op. Cit. p. 27/28
} 
concepção, segundo o jurista, possui sólido alicerce na ordem constitucional brasileira, estando amparada na moralidade pública da democracia.

Muito embora sejam assegurados na Constituição diversos direitos que integram a autonomia, tais como a liberdade de expressão, religião e profissional, inexiste proteção expressa no sentido de reconhecer o sujeito como agente capaz de fazer e seguir escolhas de vida, defendido das pressões opressoras e paternalistas do Estado e da sociedade. Sendo assim, a dignidade humana é justamente o que proporciona essa garantia.

Partindo-se do pressuposto de que a dignidade da pessoa humana é concebida como autonomia na Constituição Federal brasileira, poder-se-ia concluir pela recepção, por parte do ordenamento jurídico brasileiro, da morte com intervenção. Ocorre que, em muitos momentos, a temática em apreço acaba por esbarrar em outro conceito essencial, qual seja, o direito à vida.

Como se sabe, o direito à vida é assegurado pelo artigo $5^{\circ}$, caput, da Constituição Federal de 1988, sendo garantida a sua inviolabilidade. Nos dizeres de José Afonso da Silva (2009, p. 198), “de nada adiantaria a constituição assegurar outros direitos fundamentais, como igualdade, a intimidade, a liberdade, o bem-estar, se não erigisse a vida humana num desses direitos”.

Da análise dos direitos fundamentais enquanto concretizadores do princípio da dignidade da pessoa humana, Ingo Sarlet (2006, p.84 e 85) afirma que a condição de valor e princípio normativo fundamental da dignidade da pessoa humana, que atrai o conteúdo de todos os direitos fundamentais, necessita e pressupõe que estes sejam reconhecidos e protegidos, em todas as dimensões. Dessa forma, não sendo assegurado à pessoa humana os direitos fundamentais inerentes e ela, se está negando-lhe a própria dignidade.

É evidente, portanto, que, sem a garantia do mais fundamental dos direitos, a própria existência humana, não seria possível garantir a dignidade. É preciso estar vivo para desfrutar de uma vida digna.

Assim, pode-se afirmar que, inicialmente, a ordem jurídica protege a vida enquanto fato natural que promove a existência. Não por outro motivo, o Código 
Penal dedica capítulo exclusivo às práticas ilícitas que violam o direito à vida, tais como o homicídio, o induzimento, instigação ou auxílio ao suicídio, o infanticídio e o aborto. Há, ainda, capítulo específico acerca dos crimes de perigo para a vida e à saúde. É justamente com base no direito de estar vivo que a legislação penal pune quase todas as formas de interrupção do sistema vital, seja na forma comissiva ou omissiva.

Por outro lado, conforme se aduziu anteriormente, da passagem da autonomia da vontade para a autonomia existencial, passou-se a conceber o indivíduo enquanto sujeito de direitos, dotado de personalidade e prerrogativas. Nesse sentido, Carlos Roberto Siqueira Castro (2007, p.285), afirma que, exatamente por este motivo, a tutela constitucional da vida passou a ser qualificada, passando a garantir, além da "facticidade do ser", determinados atributos e condições para o exercício da personalidade humana em sua forma plena. O autor vai adiante, afirmando que a mencionada "plenitude da personalidade humana" pode ser concebida de diferentes formas a depender do regime político-constitucional sob o qual estiver inserida. Em um Estado Democrático de Direito, assevera que tutelar constitucionalmente a vida significa compreender a existência digna e em regime de liberdade, igualdade e segurança. Estes fatores irão permitir o desenvolvimento social da individualidade, conforme previsto pelo artigo $5^{\circ}$ da Constituição da República. A ótica amplificada da tutela do ser individual, associando os direitos da personalidade ao direito à vida em sociedade, protege não só a conservação da existência, o estar vivo biologicamente, como também e, principalmente, as "zonas de integridade" que envolvem o indivíduo, constituídas pela integridade física, moral e social.

Aliado a isto, conforme demonstrado anteriormente, o Princípio da Dignidade da Pessoa Humana, enquanto princípio norteador da República Federativa do Brasil, conforme assegurado pelo artigo $1^{\circ}$, III, da Constituição Federal de 1988, guarda com o resto do texto constitucional e infraconstitucional relação de observância necessária. O ordenamento jurídico brasileiro deve ser, portanto, elaborado e interpretado de forma sistemática. Assim, além de a dignidade da pessoa humana necessitar da existência dos direitos fundamentais 
para ser experimentada, também é preciso que estes direitos sejam assegurados de acordo com ela. Há, portanto, uma relação de interdependência. Nesse sentido, o jurista Carlos Roberto Siqueira Castro (2007, p. 283) expõe que:

“[...] a proteção à vida, que constitui o primeiro e mais fundamental dos direitos tutelados no caput do artigo $5^{\circ}$ da Constituição da República, cuja inviolabilidade é garantida a todos os brasileiros e estrangeiros residentes no país, refere-se não apenas e objetivamente ao estado de ser vivo, mas a um modo qualificado de exercer os predicados da existência, o que vale dizer - de acordo com os padrões de dignidade existencial que a própria Lei Maior, em disposições dispersas, reputa essenciais ao direito de viver. Nesse sentido, o direito à vida retrata o direito de viver uma vida digna segundo a valoração jurídico-social do que deva ser a existência com dignidade.”

Quanto à esta relação de interdependência entre dignidade da pessoa humana e direitos fundamentais, Ingo Sarlet (2006, p. 83) afirma que, muito embora não seja possível correlacionar todos os direitos fundamentais de forma direta e em mesmo grau de intensidade ao princípio da dignidade da pessoa humana, necessariamente todos são reconduzidos de alguma forma à noção de dignidade, já que "todos remontam à ideia de proteção e desenvolvimento das pessoas, de todas as pessoas [...]".

Nesse sentido, admitindo que a compreensão de dignidade repousa na autonomia pessoal, ou seja, na liberdade que o ser humano possui, ainda que de forma potencial, de formatar sua própria existência e ser sujeito de direitos, não mais se questiona que a liberdade e os direitos fundamentais necessários à sua proteção constituem, ao mesmo tempo, pressuposto e concretização da dignidade da pessoa. O entendimento, então, de que sem liberdade - seja ela negativa ou positiva - não haverá dignidade, parece difícil de ser questionado.

Assim, entendendo que é através da liberdade que o individuo estará apto a exercer seus direitos fundamentais de forma plena, realizando a si mesmo de forma autônoma e em busca do desenvolvimento de sua pessoalidade e identidade, forçoso reconhecer que utilizará ao longo da vida seus próprios parâmetros acerca do que considera bom ou valioso para si.

Tendo em vista que o objetivo da sociedade moderna é a viabilização da liberdade para que o indivíduo construa sua pessoalidade, sendo esta 
compreendida por expectativas e propostas de autorrealização individual, a frustração destes projetos, com base em argumentos moralistas ou estigmatizantes, implica em desrespeito à autodeterminação do próprio sujeito.

No que tange à morte assistida, conceder permissão para que a pessoa determine o seu fim é reconhece-la enquanto agente da própria vida. É imprescindível reconhecer que a pessoa possui outras dimensões que não somente a biológica, devendo-se aceitar que quando o indivíduo opta por não só estar vivo, como ter qualidade de vida, ele está a serviço do seu projeto autobiográfico.

Se os projetos de uma sociedade fraterna e pluralista reconhecem a possibilidade de convívio de variados projetos de vida, a dignidade da pessoa humana pressupõe, inclusive, o direito subjetivo à morte.

Esse argumento nos leva a uma nova interpretação do fundamento constitucional previsto no art. $1^{\circ}$, inciso III, (dignidade da pessoa humana), bem como do direito fundamental à vida, previsto no art. $5^{\circ}$, caput, da Constituição da República. Portanto, necessário repensar o direito infraconstitucional, readequando-o à Constituição, sobretudo àquelas normas que tratam do direito subjetivo a morrer com dignidade.

\section{3 - CONSENSOS E PROPOSTA DE REGULAMENTAÇÃO À MORTE COM INTERVENÇÃO}

Partindo-se do pressuposto de que tanto o artigo $1^{\circ}$, inciso III, quanto o artigo $5^{\circ}$, caput, ambos da Constituição Federal, asseguram o direito à morte com intervenção, isto é, a morte digna, parte da doutrina sustenta a possibilidade de regulamentação desse direito desde que determinados requisitos sejam observados. Verifica-se, outrossim, forte influência da legislação comparada na concepção e elaboração das condições elencadas. 
Maria de Fátima Freire Sá ${ }^{56}$ aponta para a necessidade de observância a 03 (três) requisitos, quais sejam, (i) o padecimento por parte do sujeito passivo de enfermidade terminal que lhe cause sofrimento, devendo a doença ser irreversível e não suscetível de tratamento, sendo necessário que à aferição do sofrimento o sujeito titular do direito atue efetivamente, (ii) o agente, aquele que executa o ato ou fornece meios para tanto, deve ser médico, já que é profissional competente para repassar ao sujeito passivo as informações necessárias quanto a sua expectativa de vida e estado de saúde, (iii) o consentimento livre e esclarecido do sujeito passivo para a prática do ato, sendo certo que este deve ter sido formado a partir de uma relação dialética entre médico e paciente.

Preenchidos os requisitos supramencionados, a conduta praticada seria considerada atípica, vez que a exclusão de sua ilicitude estaria assegurada constitucionalmente, já que, como visto, a morte digna possui respaldo constitucional.

Quanto ao requerimento do paciente, a autora aduz pela necessidade em se evidenciar seu caráter autônomo, de modo que a decisão deve ter sido tomada sem qualquer influência de fatores externos, como por exemplo, a privação econômica ou o receio de se tornar um estorvo à família.

Outrossim, a exemplo do que também ocorre em legislações alienígenas, sustenta Luis Roberto Barroso ${ }^{57}$, que a regulamentação da morte assistida, em que se valoriza autonomia, tanto o paciente, ou seu responsável, como o médico poderão se abster de realizar o procedimento. Não se trata, em hipótese alguma, de um dever, tão somente um direito. $\mathrm{O}$ autor assevera, ainda, que, tratando-se de ordenamento jurídico em que se trata de maneira adequada a ortotanásia, tanto a eutanásia, quanto o suicídio assistido, acabariam por se tornar medidas excepcionais.

\footnotetext{
${ }^{56}$ SÁ, Maria de Fátima Freire; MOUREIRA, Diogo Luna. O direito subjetivo à morte digna: uma leitura do direito brasileiro a partir do caso José Ovídio González. Civilistica.com. Rio de Janeiro. 2016. p. 13

${ }^{57}$ BARROSO, Luis Roberto; MARTEL,Letícia de Campos Velho. Op. Cit. p.31
} 
Outrossim, conforme, conclui o autor, tendo em vista que o debate acerca do suicídio assistido e da eutanásia é permeado por questões filosóficas mais complexas, em território brasileiro, o caminho possível à regulamentação da morte com dignidade seria por via do tratamento correto da ortotanásia. Por fim, aponta proposições que considera como compatíveis com a Constituição e a legislação em vigor, quais sejam, a limitação consentida de tratamento, o cuidado paliativo e o controle da dor, a implantação de Comitês Hospitalares de Bioética, a educação dos profissionais e a informação ao público.

\section{CONCLUSÃO}

O cenário da pré-morte representa, muitas vezes, uma névoa verdadeiramente aterradora, em que são protagonistas pessoas terrivelmente incapacitadas, entubadas, completamente inconscientes, que têm suas vidas mantidas por dúzias de aparelhos que os forçam a continuar em vida. A evolução tecnológica tem sido responsável por tornar estes cenários ainda mais comuns, vez que aparelhos mais evoluídos têm sido postos à disposição de hospitais.

$\mathrm{O}$ presente estudo procurou refletir sobre a morte assistida à luz do princípio da dignidade da pessoa humana e do direito à vida, analisando como a legislação doméstica lida com o tema, bem como a forma como o fenômeno repercute em legislações alienígenas. Verificou-se que, muito embora exista um movimento internacional, inclusive por parte de países sul-americanos, em descriminalizar a prática, a discussão não obteve grandes avanços em território brasileiro.

Viu-se, inicialmente, que a prática do suicídio assistido, da eutanásia e da ortotanásia, é punida pela legislação brasileira por via do Código Penal, seja através de artigo específico - artigo 122, quando do suicídio assistido -, seja através do artigo 121, que trata do crime de homicídio. Nesse sentido, enquanto por parte do artigo 122 não é possível verificar qualquer redução de pena relacionada ao íntimo do agente, quando se trata da eutanásia ou da ortotanásia, existe uma 
convergência doutrinária em se admitir que o homicídio seja considerado privilegiado.

Quando deslocada para o cenário internacional, a discussão recebe outros contornos. Países como a Holanda, Bélgica, Luxemburgo, Canadá e determinados estados dos Estados Unidos, passaram por modificações legislativas admitindo a prática da morte com intervenção. Já países como a Colômbia e o Uruguai, muito embora criminalizem a prática por via legislativa, têm sido palco para verdadeiro ativismo judicial, sendo possível verificar decisões que já toleram a morte assistida. Verificou-se que um dos grandes desafios em se admitir a morte assistida em países democráticos é o de entendê-la como um ato de expressão do livre arbítrio individual. A preocupação da legislação estrangeira repousa principalmente na necessidade de regulamentação para se garantir que o exercício desse direito seja livre, informado e consciente.

Iniciada a discussão do fenômeno da morte assistida à luz do princípio da dignidade da pessoa humana, buscou-se analisar as origens da sua consagração enquanto marco civilizatório, bem como seu papel na passagem do conceito de autonomia contratual à autonomia existencial. Nesse contexto, verificou-se que a autonomia existencial concebe ao indivíduo um campo de liberdade para a emancipação de seus atributos pessoais enquanto sujeito de direito.

Considerando que a Constituição Federal de 1988 foi promulgada em um contexto histórico de ruptura com um estado ditatorial e totalitário, muito embora seja possível verificar determinados momentos em que a dignidade é vista de forma heterônoma, fato é que sua expressão máxima é aquela que valoriza o indivíduo e sua liberdade, sendo um fim em si mesmo. A dignidade é tida, então, como autonomia individual pelo texto legal.

A dignidade como autonomia é considerada por muitos como suficiente para legitimar diferentes modalidades de morte assistida, sendo certo que o consentimento fornecido pelo paciente deve ser voluntário, suficientemente embasado e livre de pressões externas.

Em contrapartida, o direito fundamental à vida é, em muitos momentos, invocado como argumento jurídico à proibição da morte com intervenção. Nessa 
direção, o direito à vida representaria verdadeiro golpe ao próprio indivíduo a quem a tutela está direcionada, o obrigando a permanecer, contra sua vontade, em estado indigno. A pretensa preservação da vida biológica pode representar verdadeira violação à dignidade.

A consagração do direito à vida no artigo $5^{\circ}$ da Carta Magna como inviolável, deve ser lida como um meio de realização para a dignidade da pessoa humana. É justamente através da vida que a dignidade humana irá se consolidar, isto é, estando vivo, o indivíduo poderá, ao longo de sua trajetória, exercer sua individualidade de forma autônoma a fim de que escreva sua própria história de acordo com seus projetos pessoais.

Nesse contexto, se propõe não a leitura antagonizada entre os dois conceitos, caso em que a escolha pela dignidade anularia o direito à vida, ou viceversa, mas sim a interpretação de que há uma certa fungibilidade entre os dois conceitos, no sentido de que onde há vida, há dignidade, e a violação de um, por conseguinte, implica na violação do outro. 


\section{BIBLIOGRAFIA}

AMERICAN MEDICAL ASSOCIATION. Code of medical ethics.

Disponível em: $\quad<\quad \mathrm{http}$ ://www.ama-assn.org/ama/pub/physicianresources/medical-ethics/code-medicalethics.shtml. > Acesso em: out. 2018

BARROSO, Luis Roberto; MARTEL, Letícia de Campos Velho.morte como ela é: dignidade e autonomia individual no fim da vida. In Vida, Morte e Dignidade da Pessoa Humana. Disponível em: < http://www.luisrobertobarroso.com.br/wpcontent/themes/LRB/pdf/a_morte _como_ela_e_dignidade_e_autonomia_no_final_da_vida.pdf $>$. Acesso nov. 2018

BARROSO, Luis Roberto. Neoconstitucionalismo e constitucionalização do direito (o triunfo tardio do direito constitucional no Brasil). Revista Eletrônica sobre a Reforma do Estado-RERE, n. 09, 2007

BITENCOURT, Cezar Roberto. Tratado de direito penal. Parte Especial. v.2. São Paulo: Saraiva, 2003.

BRASIL. Constituição (1988) Constituição da República Federativa do Brasil. Disponível em: < http://www.presidencia.gov.br/legislacao > Acesso em: 20 de novembro de 2018.

BRASIL. MINISTÉRIO PÚBLICO FEDERAL. ACP $\mathrm{n}^{\mathbf{0}}$ 2007.34.00.014809-3. Petição Inicial (Wellington Divino Marques de Oliveira - Procurador Regional dos Direitos do Cidadão/1ª Região). Disponível em: $\quad<\quad$ http://noticias.pgr.mpf.gov.br/noticiasdosite/pdfs/ACP\%20Ortotanasia.pdf > . Acesso em: out de 2018.

BRASIL. MINISTÉRIO PÚBLICO FEDERAL. Recomendação nº1/2006 WD - PRDC. (Wellington Divino Marques de Oliveira - Procurador Regional dos Direitos do Cidadão/1 ${ }^{\mathrm{a}}$ Região). Disponível em: < 
http://prdc.prdf.mpf.gov.br/legis/docs/exfile.2006-1121.7242563592/attach /REC\%2001-2006\%20CFM.pdf . > Acesso em: out de 2018.

BRASIL. SENADO FEDERAL. Projeto de Lei nº116/2000. Disponível em: http://www.senado.gov.br/sf/atividade/materia/getPDF.asp?t=71461

BRASIL. SENADO FEDERAL. Projeto de Lei n524/2009. Disponível em: http://legis.senado.gov.br/mate-pdf/70139.pdf

CANADÁ. Canadian Charter of Rights and Freedoms. 1982. Disponível em: http://lois.justice.gc.ca/en/charter/index.html. Acesso em: set. 2018

COLOMBIA. Sentencia C-239/97. Demanda de Inconstitucionalid contra el artículo 326 del decreto 100 de 1980 - Código Penal. Magistrado Ponente: dr. Carlos Gaiviria Diaz. 20 de mayo de 1997. Disponível em: http://web.minjusticis.gov.co/jusrisprudencia Acesso em: out. de 2018

CONSELHO FEDERAL DE MEDICINA. RESOLUÇÃO CFM 1.805. BRASILIA, 09 DE NOVEMBRO DE 2006.

Disponível em:

http//www.portalmedico.org.br/resouçoes/cfm/2007/111_2007.htm > Acesso em: 20 de nov. 2018.

CONSELHO FEDERAL DE MEDICINA. RESOLUÇÃO CFM 1.995. BRASILIA, 09 DE AGOSTO DE 2012. Disponível em: < $\mathrm{http} / /$ www.portalmedico.org.br/resouçoes/cfm/2007/111_2007.htm > Acesso em: 20 de nov. 2018.

DINIZ, Débora. Quando a morte é um ato de cuidado: obstinação terapêutica em crianças. Cadernos de Saúde Pública, v.22, n.8, ago. 2006.

DWORKIN, Ronald. Domínio da Vida. São Paulo. Martins Fontes, 2003 
GODINHO, Adriano Marteleto et al. (Org.). Tratado Brasileiro sobre o Direito Fundamental à Morte Digna. São Paulo: Almedina Brasil, 2017. $387 \mathrm{p}$.

HUNGRIA, Nelson. Comentários ao código penal. Rio de Janeiro: Forense, 1981, 422 p.

JOSÉ MANUEL, Pinto; TERESA, Montalvão da Cunha. Eutanásia e Suicídio Assistido. 2016. Disponível em

$<$ https://www.parlamento.pt/ArquivoDocumentacao/Documents/Eutanasia SuicidioAssistido1.pdf>

LUXEMBURGO. Loi du 16 mars 2009 relative aux soins palliatifs, à la directive anticipée et à l'accompagnement en fin de vie. Memorial. Journal Officiel du GrandDuché de Luxembourg. Disponível em: http://www.legilux.public.lu/leg/a/archives/2009/0046/a046.pdf\#page=7

.Acesso em: out./2018.

MARTEL, Letícia de Campos Velho. Direitos fundamentais indisponíveis - Os limites e os padrões do consentimento para a autolimitação do direito fundamental à vida. Dissertação de Doutorado da Universidade do Estado do Rio de Janeiro. 2010. Disponível em < http://pct.capes.gov.br/teses/2010/31004016015P4/TES.PDF > Acesso nov. 2018

MARTEL, Letícia de Campos Velho. Limitação de tratamento, cuidado paliativo, eutanásia e suicídio assistido: elementos para um diálogo sobre os reflexos jurídicos da categorização. In: BARROSO, Luís Roberto. A reconstrução democrática do direito público no Brasil. Rio de Janeiro: Renovar, 2007.

PESSINI, Leocir. Eutanásia: Por que abreviar a vida?. São Paulo: Loyola, 2004. 376 p.

SÁ, Maria de Fátima Freire de; MOUREIRA, Diogo Luna. O direito subjetivo à morte digna: uma leitura do direito brasileiro a partir do caso José Ovídio González. Civilistica.com. Rio de Janeiro, a. 5, n. 2, 2016. Disponível em: $<\quad$ http://civilistica.com/wpcontent/uploads/2016/12/S\%C3\%A1-e-Moureira-civilistica.coma.5.n.2.2016.pdf .> acesso em nov. 2018 
REGIS PRADO, Luiz. Tratado de Direito Penal Brasileiro: Parte Especial Arts. 121 ao 183. 2 ${ }^{\text {a }}$ ed. [S.1.]: Rt - Revista Dos Tribunais, 2017.

SÁ, Maria de Fátima Freire de. Direito de morrer: eutanásia e suicídio assistido. Belo Horizonte: Del Rey, 2001.

SARLET, Ingo Wolfgang. Dignidade da Pessoa Humana e Direitos Fundamentais: na Constituição Federal de 1988. 4a . ed. Porto Alegre: Livraria do Advogado, 2006. 158 p.

SARMENTO, Daniel. Dignidade da Pessoa Humana: conteúdo, trajetórias e metodologia. Belo Horizonte: Fórum, 2016.

SARMENTO, Daniel et al. (Org.). Nos Limites da Vida: Aborto, Clonagem Humana e Eutanásia sob a Perspectiva dos Direitos Humanos. [S.1.]: Lumen Juris Ltda., 2007. 307 p.

SILVA, José Afonso da. A dignidade da pessoa humana como valor supremo da democracia. In:

São Paulo: Malheiros, 2000. p. 144-149. Poder constituinte e poder popular. 
Pontifícia Universidade Católica $_{\text {a }}$

DO RIO DE JANEIRO

NORMAS PARA ELABORAÇÃO E APRESENTAÇÃO DA MONOGRAFIA

ANEXO II

A Monografia deve ser entregue até o dia 21 de novembro de 2018

A presente Monografia, apresentada pelo (a) aluno (a) ALiCE MAC DOWEll VERAS

poderá ser submetida à exposição e defesa perante a Banca Examinadora designada pelo Departamento de Direito da PUC-Rio.

Rio de Janeiro, 21 de NOVEMBRO de 2018.

ANDRÉ PERECMANIS

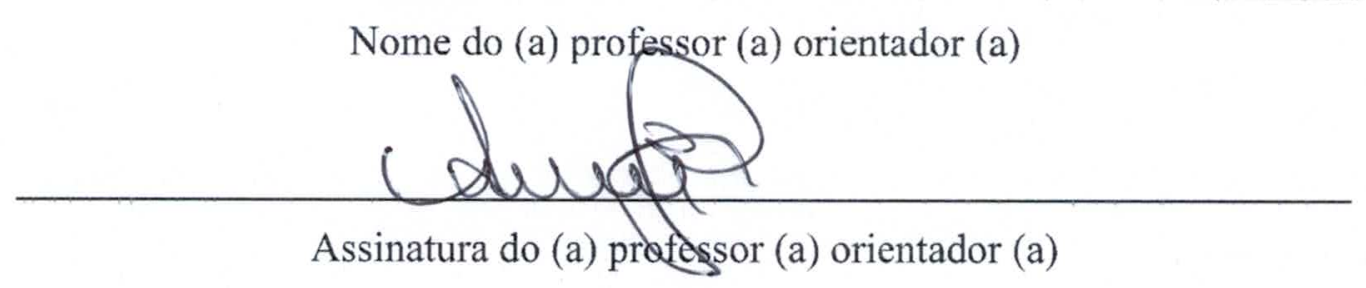

O (A) autor (a) deste trabalho declara para todos os fins de Direito ser este um trabalho inédito e autoriza o Departamento de Direito da PUC-Rio a divulgá-lo, no todo ou em parte, resguardados os direitos autorais conforme legislação vigente.

Rio de Janeiro, a1 de nevembro 2018.

Alice Mac Dowell Veras

Assinatura do (a) aluno (a) 